Research paper

\title{
New 1,3-thiazole derivatives and their biological and ultrastructural effects on Trypanosoma cruzi
}

\author{
Paulo André Teixeira de Moraes Gomes a, Miria de Oliveira Barbosa a, \\ Edna Farias Santiago a , Marcos Veríssimo de Oliveira Cardoso ${ }^{\mathrm{b}}$, \\ Natáli Tereza Capistrano Costa a, Marcelo Zaldini Hernandes a, \\ Diogo Rodrigo Magalhães Moreira ${ }^{c}$, Aline Caroline da Silva ${ }^{\mathrm{d}}$, \\ Thiago André Ramos dos Santos ${ }^{\mathrm{d}}$, Valéria Rêgo Alves Pereira ${ }^{\mathrm{d}}$, \\ Fábio André Brayner dos Santosd ${ }^{\mathrm{d}}$, Glaécia Aparecida do Nascimento Pereira e, f, \\ Rafaela Salgado Ferreira ${ }^{\mathrm{f}}$, Ana Cristina Lima Leite ${ }^{\mathrm{a} \text {, * }}$ \\ a Departamento de Ciências Farmacêuticas, Centro de Ciências da Saúde, Universidade Federal de Pernambuco, 50740-520, Recife, PE, Brazil \\ b Universidade de Pernambuco, 56328-903, Petrolina, PE, Brazil \\ c Centro de Pesquisas Gonçalo Moniz, Fundação Oswaldo Cruz, CEP 40296-750, Salvador, BA, Brazil \\ d Centro de Pesquisas Aggeu Magalhães, Fundação Oswaldo Cruz, CEP 50670-420, Recife, PE, Brazil \\ e CAPES Foundation, Ministry of Education of Brazil, Brasília, DF, Brazil \\ f Departamento de Bioquímica e Imunologia, Universidade Federal de Minas Gerais, CEP 31270-901, Belo Horizonte, MG, Brazil
}

\section{A R T I C L E I N F O}

Article history:

Received 24 March 2016

Received in revised form

5 May 2016

Accepted 22 May 2016

Available online 24 May 2016

Keywords:

Antiprotozoal agents

Chagas disease

Thiazole

Hydrazones

Cruzain

Electron microscopy

\begin{abstract}
A B S T R A C T
In previous studies, the compound 3-(bromopropiophenone) thiosemicarbazone was described as a potent anti-Trypanosoma cruzi and cruzain inhibitor. In view to optimize this activity, 1,3-thiazole core was used as building-block strategy to access new lead generation of anti $T$. cruzi agents. In this way a series of thiazole derivatives were synthesized and most of these derivatives exhibited antiparasitic activity similar to benznidazole (Bzd). Among them, compounds (1c) and (19) presented better selective index (SI) than Bzd. In addition, compounds showed inhibitory activity against the cruzain protease. As observed by electron microscopy, compound (1c) treatment caused irreversible and specific morphological changes on ultrastructure organization of $T$. cruzi, demonstrating that this class of compounds is killing parasites.
\end{abstract}

๑) 2016 Elsevier Masson SAS. All rights reserved.

\section{Introduction}

Parasitic diseases continue to take an enormous toll on human health, particularly in tropical regions [1]. Chagas disease, caused by Trypanosoma cruzi, represents a serious and alarming health problem [2]. It is considered to be one of the most concerning infectious tropical disease in Latin America [3].

Currently, the only drug in use is nitroheterocyclic benznidazole, which is effective in curing the disease in the acute phase, but is less effective in patients that progressed to the chronic phase [4,5].

\footnotetext{
* Corresponding author.

E-mail address: acllb2003@yahoo.com.br (A.C.L. Leite).
}

Furthermore, benznidazole is less than ideal due to the fact that it causes severe side effects, leading to treatment interruption in a large number of patients [6].

Trypanosomes contain an abundance of cysteine proteases (CPs) which are members of the papain superfamily [7]. The cysteine peptidases present stage-regulated levels, are important virulence factors, modulate mammalian host immune cells and facilitate tissue host invasion, what makes these proteases attractive potential targets for chemotherapy [8]. Cruzain is the major Trypanosoma cruzi cysteine protease and it has been identified as a crucial enzyme responsible for parasite invasion, differentiation and proliferation in host cells [10]. Among its functions, cruzain induces the production of the proinflammatory peptide Lys bradikinin directly by proteolysis of kininogen or by activation of 
plasmatic pre-kallikrein [9], therefore contributing to the outcome of the infection [11].

Regarding the identification of cruzain inhibitors, most of the efforts have been conducted through the investigation of peptides and peptide-like compounds, such as ureas [9,10], hydrazones [11-14], triazoles [15,16] and thiosemicarbazones [17-19].

Thiosemicarbazones have been largely investigated as antiT. cruzi agents $[17,18,20-24]$. Originally, thiosemicarbazones were developed as potential inhibitors of cathepsin-L inhibitors, one of the main proteases involved in cancer development [17]. However, based on the homology and similar biochemical properties between cathepsin-L and cruzain, thiosemicarbazones were investigated as a potential class of cruzain inhibitors. Later on, aryl thiosemicarbazones were found to be a class of anti-T. cruzi compounds that inhibits cruzain activity $[18,19]$.

Du and co-workers [17] thus identified twelve potent cruzain inhibitors that presented $\mathrm{IC}_{50}$ values below $200 \mathrm{nM}$. Of the active aryl-thiosemicarbazones, the target compound 3-(bromopropiophenone) thiosemicarbazone (1) was able to inhibit cruzain at a concentration of $100 \mathrm{nM}$ in a time-dependent manner, evidencing the reversible inactivation on the enzyme. Remarkable differences in potency were observed across the congeneric series, probably reflecting the importance of the steric factor in binding to the enzyme. Interestingly, several pyrazoline derivatives seem to be more conformational restricted analogues than arylthiosemicarbazones, and have been shown to be as potent as aryl-thiosemicarbazones against cruzain and to act in a similar fashion against the parasite in vitro, being a typical example of a classic bioisosteric relationship between cyclic and non-cyclic scaffolds [25]. This successful example of cruzain inhibitor has led to increased efforts to find new compounds structurally related to $\mathbf{1}$.

1,3-Thiazole, the cyclic analogue of thiosemicarbazone, is one of the most important scaffolds in heterocyclic chemistry and drug design and discovery. It is widely found in diverse pharmacologically active substances and in some naturally occurring compounds [26]. Thiazole is a versatile building-block for lead generation, and it allows easy access of diverse derivatives for subsequent lead optimization [26]. In recent years, many thiazole derivatives have been synthesized and subjected to varied biological activities [26]. Our efforts toward new antiparasitic drug since 2006 have led us to a variety of thiosemicarbazones and thiazolyl hydrazones as trypanocidal agents [27-31].

Promising results achieved by compounds bearing a 1,3-thiazole ring motivated us to investigate the trypanocidal activity of novel thiazolyl hydrazones derived from 3-(bromopropiophenone) thiosemicarbazone (1) firstly identified by Du and co-workers [17]. Thus, in this work, the thiosemicarbazone $\mathbf{1}$ was converted into a set of 4-phenyl-thiazolyl hydrazine, and the effect of antiparasitic activity of different substituents attached at C4 of 1,3-thiazole was investigated. We also studied the influence of a methyl group at the C5 carbon of the thiazole ring, both in the presence or absence of a substituent at the para position of the aromatic ring attached to the 1,3-thiazole and the effect of a methyl or phenyl group at N3 of 1,3thiazole ring on the antiparasitic activity. (Fig. 1).

\section{Results and discussion}

\subsection{Chemistry}

The following thiosemicarbazones 3-(bromopropiophenone)thiosemicarbazone (1), 2-[1-(3-bromophenyl)propylidene]-Nmethylhydrazinecarbothioamide (2) and 2-[1-(3-bromophenyl) propylidene]-N-phenylhydrazinecarbothioamide (3) were prepared by reacting commercially available 3 '-bromophenyl-1propanone with corresponding thiosemicarbazide, under reflux in the presence of catalytic $\mathrm{HCl}$. These intermediate compounds then react with different $\alpha$-halogenated ketones, obtaining the 1a-3c series with yields of $57-72 \%$ (Scheme 1). All compounds were identified by infrared (IR) and nuclear magnetic resonance $\left({ }^{1} \mathrm{H}\right.$ NMR and ${ }^{13} \mathrm{C}$ NMR) spectroscopy, mass spectra (ESI-TOF) and their purity was established by elemental analysis (EA).

NMR data are compatible with the proposed compounds. In theory, two geometrical isomers $(E$ and $Z)$ about the imine $(C=N)$ double bond are possible for the thiosemicarbazones and the respective thiazoles. However, analysis of the ${ }^{1} \mathrm{H}$ NMR spectra of the compounds indicated one predominant isomer; the $E$ isomer by comparison with known analogues [32]. Intramolecular H-bonding involving the proton attached to N4 (in DMSO) with the imine Natom leads to a distinctive singlet around $10.2 \mathrm{ppm} \mathrm{[32]} \mathrm{and} \mathrm{this} \mathrm{is}$ also seen here.

Once thiosemicarbazones were characterized, the respective 1,3-thiazoles were characterized by usual spectroscopy. As exemplified with the ${ }^{1} \mathrm{H}$ NMR analysis of (E)-4-(biphenyl-4-yl)-2-\{2-[1(3-bromophenyl)propylidene]hydrazinyl\}thiazole (19), the triplet peak at $\delta 1.29$ and the quartet peak at $\delta 2.92$ correspond to the ethyl group. For the aromatic protons, singlet, doublets or triplets peaks were observed at $\delta 7.19-7.87$. For the thiazole ring, a singlet at $\delta 6.76$ was found. $\mathrm{NH}$ proton appeared as singlet at $\delta 12.89$. In ${ }^{13} \mathrm{C}$ NMR spectrum of $1 \mathrm{~g}$, peaks $\delta 11.1$ and $22.4 \mathrm{ppm}$ correspond to carbons of ethyl group. Peaks of the aromatic carbons were found at $\delta 123.0-140.7 \mathrm{ppm}$. The presence of peaks at $\delta 101.1$ and $170.0 \mathrm{ppm}$, confirm the thiazole cyclization.

The ${ }^{1} \mathrm{H}$ NMR spectra of $\mathbf{2 c}$ and $\mathbf{3 c}$ compounds showed that they are composed by diastereomers. Based on previous crystallized compounds by our group, we suggest that the major isomer formed present the $E-Z$ configuration (Fig. 2). Indeed, hydrazine doublebond $\mathrm{C} 2=\mathrm{N} 2$ is commonly assigned as $E$ configuration $[3,31,33,34]$. Concerning the exocyclic double-bond $N 3=C 3$, we suggest that the predominant configuration is $Z$ [17,18,20-24,27,35]. Besides, a representative ${ }^{1} \mathrm{H}$ NMR spectrum of compound $\mathbf{2 c}$ is presented in Supplementary Material.

\subsection{Cytotoxicity and anti-T. cruzi activity}

Comparing host cell cytotoxicity between thiosemicarbazone $\mathbf{1}$ and 1,3-thiazole 1a, a 2-fold lower cytotoxicity for splenocytes is observed. The insertion of substituents at the para position of the aromatic ring attached at C4 (1,3-thiazole) in series $\mathbf{1 a - m}$ reduces the toxicity of eight compounds (1a-g and 1k). Comparing nonsubstituted compound 1a with 1b (4-methyl substituted) it can be observed that the last is 2-fold less toxic. However, substitution at position $3\left(\mathbf{1 h}, 3-\mathrm{NO}_{2}\right)$ and di-substitutions at positions $2,4(\mathbf{1 j}$, dichloro) or 3,4 (1i , dichloro) do not reduce toxicity when compared with compound 1a (Table 1 ).

The introduction of a methyl at $\mathrm{C} 5$ position of thiazole ring (compounds $\mathbf{1 1}$ and $\mathbf{1 m}$ ) do not reduce the toxicity. Moreover, comparing compound $\mathbf{1}$ with $\mathbf{2}$ and $\mathbf{3}$, it can be seen that the introduction of a methyl (2) at N3 of thiosemicarbazone kept the cytotoxicity, however the substitution with phenyl (3) lead to a 4fold reduction of cytotoxicity. When the host cell cytotoxicity was compared to Bzd, eight compounds were less toxic (1)-c, 1d-g, 1k and 3), being compounds 1f $\left(4-\mathrm{NO}_{2}\right), \mathbf{1 g}(4-\mathrm{Ph}-\mathrm{Ph})$ and $\mathbf{1 k}(2-$ naphthyl) devoid of toxicity in spleen cells (Fig. 3 ).

Concerning activity against trypomastigotes, the conversion of thiosemicarbazone (1) in 1,3-thiazoles increased the activity, which led us to identify five compounds with similar activity to Bzd (1a, 1c, 1g, 11 and 1m). Specifically, compound 1a showed activity and selectivity index similar to Bzd. In contrast, the substitution of phenyl at C4 (1a) by 2-naphthyl (1k) led to a reduction of activity against trypomastigote form. 


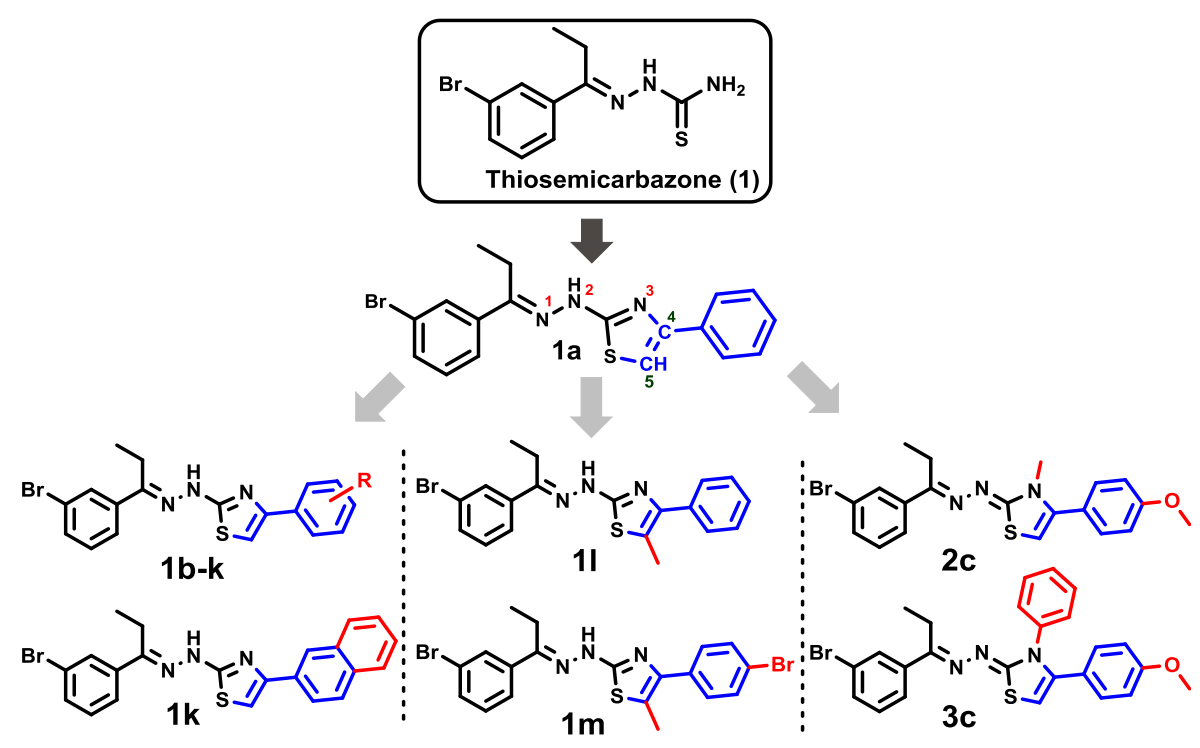

Fig. 1. Structural planning of the proposed series of compounds.<smiles>CCC(=O)c1cccc(Br)c1</smiles>

1-(3-bromophenyl)propan-1-one

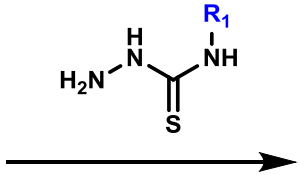

a)<smiles>[R7]NC(=S)N/N=C(\CC)c1cccc(Br)c1</smiles>

$1-3$

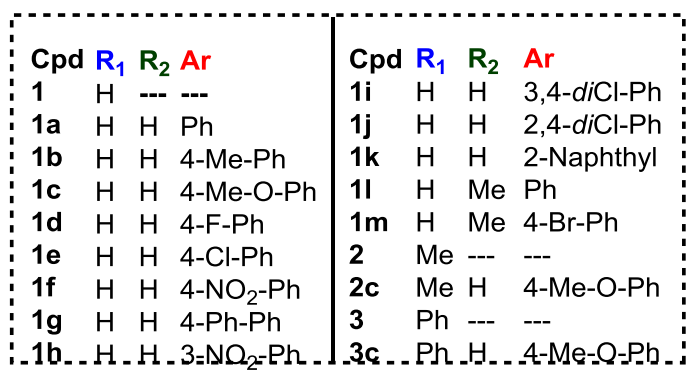<smiles>[R2]c1s/c(=N\N=C(/CC)c2cccc(Br)c2)n([R1])c1Br</smiles>

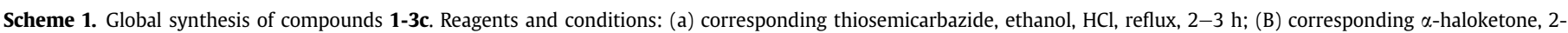
propanol, rt, $1 \mathrm{~h}$.

Halogens in para position (1d and 1e) of aromatic ring attached to thiazole lead to reduced activity in trypomastigotes. The presence of a methyl (2c) or phenyl (3c) substituent at N3 (thiazole) was also not beneficial to antiparasitic activity. Although the presence of methyl at C5 of thiazole ring was beneficial to cytotoxicity in splenocytes, it improved the antiparasitic activity, as seen with compounds $\mathbf{1 1}$ and $\mathbf{1 m}$.

Derivatives 1c (4-OMe) and 1g (4-Ph-Ph) presented better antiparasitic activity, with 1c showing a selectivity index (cytotoxicity/ $/ \mathrm{IC}_{50}$ trypomastigote) about two-times better than Bzd and 1. These results may indicate that the methoxy group present in the molecule $\mathbf{1 c}$ is an important substituent for antiparasitic activity.

The compound $1 \mathrm{~g}$ (4-Ph-Ph) showed a parasite selectivity 4folds great than Bzd and compound 1. Concerning compound 1k, which contains a bulky 2-naphthyl group, it did not present good trypanocidal activity. The main difference about $\mathbf{1 g}$ and $\mathbf{1 k}$ is that $\mathbf{1 g}$ present more flexibility than $\mathbf{1 k}$, indicating that steric effect and lipophilicity of substituents is not directly related to trypanocidal activity, being mainly flexibility features an important tool to be explored in the future.

Even though thiosemicarbazone (1), synthesized firstly by $\mathrm{Du}$ et al. presented the lowest $\mathrm{IC}_{50}$ value against trypomastigote form, compounds 1c and $\mathbf{1 g}$ showed the highest SI values, (31.3 and 64.5 respectively) being thus promising anti-T. cruzi candidates (Fig. 4).

\subsection{Cruzain inhibition}

In view to investigate a possible biologic target, compounds were tested against the enzyme cruzain of the T. cruzi. Enzyme inhibition was measured using a fluorimetric assay with the 
A<smiles>[R]n1c(-c2ccc(OC)cc2)cs/c1=N\N=C(/C)c1cccc(Br)c1</smiles><smiles>[R]n1c(-c2ccc(OC)cc2)cs/c1=N\N=C(/CC)c1cccc(Br)c1</smiles>
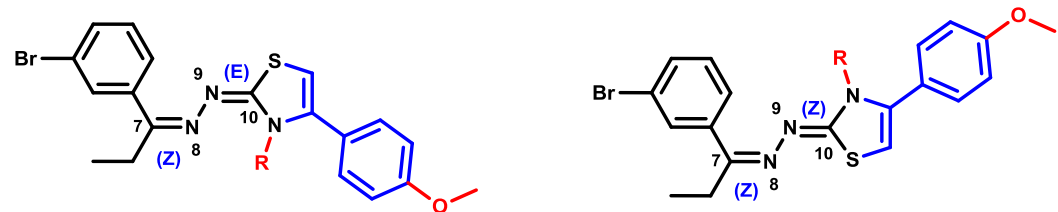

B<smiles>[R]n1c(-c2ccc(OC)cc2)cs/c1=N\N=C(/C)c1cccc(Br)c1</smiles>

\section{$\mathrm{R}=$ Methyl (2c) or Phenyl (3c)}

Fig. 2. Isomers representation of compounds $\mathbf{2 c}$ and $\mathbf{3 c}$. A- Possible isomers for compounds $\mathbf{2 c}$ and $\mathbf{3 c}$. B- Suggested isomer for compounds $\mathbf{2 c}$ and $\mathbf{3 c}$.

Table 1

In vitro effect of 3'-(bromopropiophenone)-hydrazinyl-thiazole derivatives on Trypanosoma cruzi (tripomatigotes) and toxicity against mouse splenocytes.

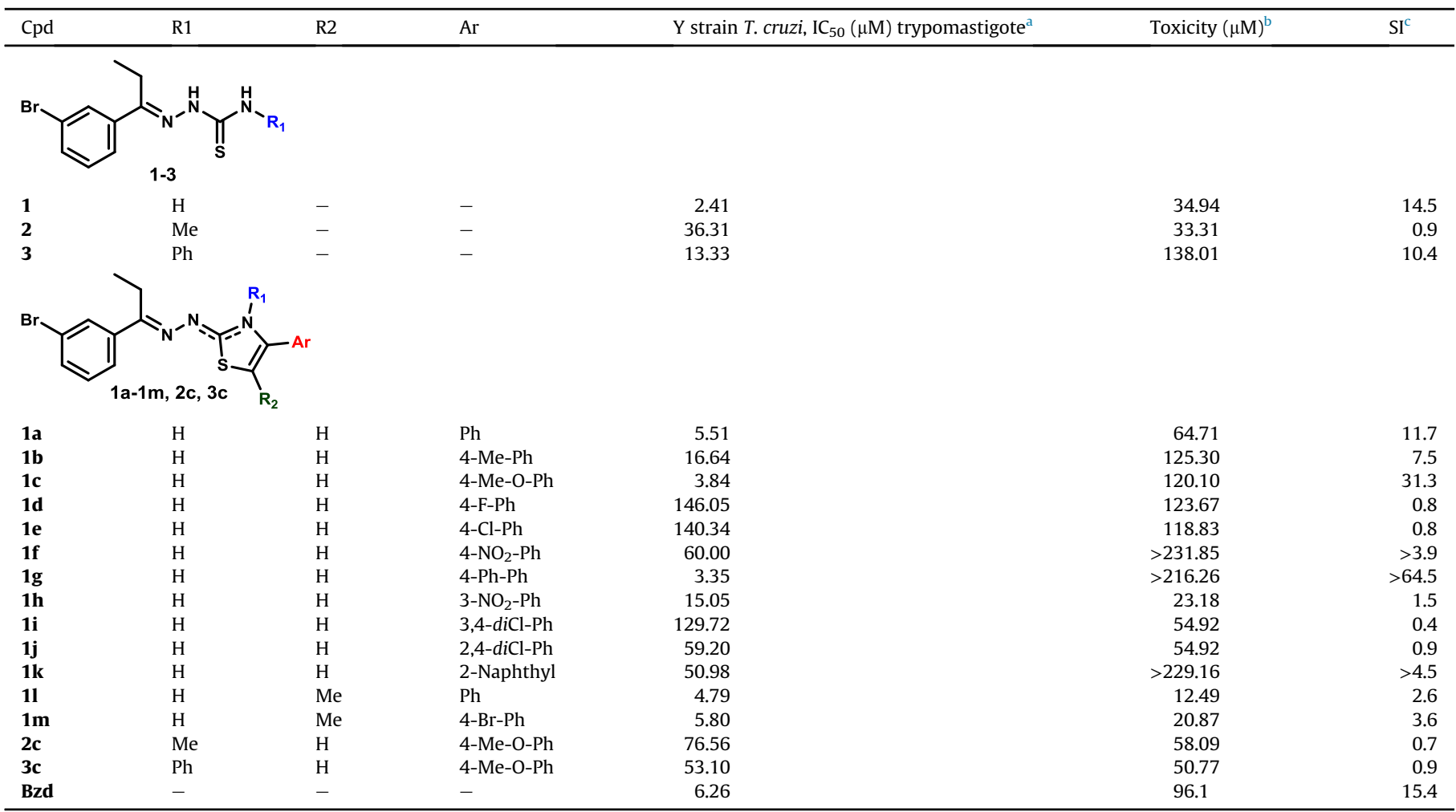

${ }^{a}$ Determined $24 \mathrm{~h}$ after incubation of trypomastigotes with the compounds. The dose-response curves were determined and the IC $\mathrm{Co}_{50}$ values $(\mu \mathrm{M})$ were calculated using at least seven concentrations.

b Highest non-toxic concentration (>90\% incorporation of tritiated thymidine) for mouse splenocytes after $24 \mathrm{~h}$ of incubation in the presence of the compounds.

c Selective Index $(\mathrm{SI})=$ Cytotoxicity $/ \mathrm{IC}_{50}$ trypomastigote. $\mathrm{Bzd}=$ benznidazole. 


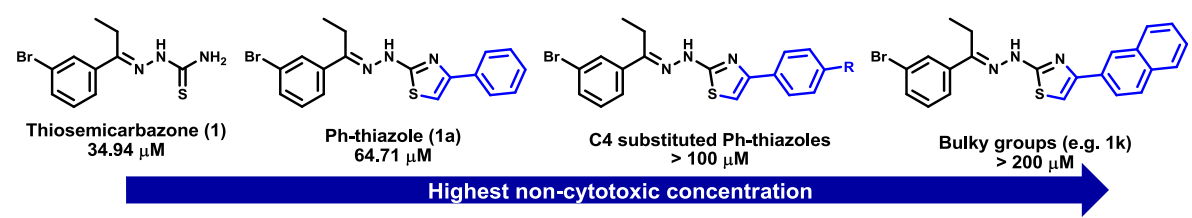

Fig. 3. Highest non-toxic concentration for mouse splenocytes.

substrate Z-Phe-Arg-aminomethylcoumarin (Z-FR-AMC) [36]. All compounds were screened at $300 \mu \mathrm{M}$ with exception of 2, 2c, 3 $(200 \mu \mathrm{M})$ and $3 \mathrm{c}(100 \mu \mathrm{M})$, which had to be evaluated at lower concentrations due to their lower solubility. Compounds that inhibited cruzain by at least $80 \%$ at the screening concentration were selected for $\mathrm{IC}_{50}$ determination (Table 2). Overall, 11 compounds had their $\mathrm{IC}_{50}$ determined, with values ranging from 0.5 to $45 \mu \mathrm{M}$.

Firstly, it was observed that a substitution at N3 for thiosemicarbazones $\mathbf{2}$ and $\mathbf{3}$ was deleterious to cruzain inhibition. Comparing compound $\mathbf{1}$ ( $\mathrm{IC}_{50}=0.04 \pm 0.00 \mu \mathrm{M}$ ) to unsubstituted thiazole $\mathbf{1 a}\left(\mathrm{IC}_{50}=44.6 \pm 2.2 \mu \mathrm{M}\right)$ it is observed that the cyclization was also deleterious for cruzain inhibition, reducing potency $100-$ fold. In fact, none of the cyclic derivatives 1a-m were more active than thiosemicarbazone 1. Comparing substituted compounds to unsubstituted 1a, it was observed that halogenated substituents (1d-e and 1i,j) at the phenyl ring slightly improved the potency against cruzain ( $\mathrm{IC}_{50} \mathrm{~S}$ ranging from 11 to $33 \mu \mathrm{M}$ ). Methoxy derivatives did not present cruzain inhibition, even substitution of methyl (1b) and phenyl (1c) at N3 did not only reduced but worsens the activity.

Methyl substituted compounds at C5, 11 and $\mathbf{1 m}$, present a reasonable potency $\left(\mathrm{IC}_{50} \mathrm{~S}=0.51 \pm 0.02 \mu \mathrm{M}\right.$ and $3.8 \pm 0.7 \mu \mathrm{M}$, respectively) highlighting compound $\mathbf{1 1}$, which improved the potency in comparison to compound 1a, unsubstituted at C5. This improvement can be due a better interaction in the active site of the enzyme. Amongst the cyclic derivatives, the most potent was compound 11, however, it shows a 12 -fold lower potency than $\mathbf{1}$ $\left(\mathrm{IC}_{50}=0.51 \pm 0.02 \mu \mathrm{M}\right.$ vs $\left.\mathrm{IC}_{50}=0.04 \pm 0.0 \mu \mathrm{M}\right)$.

Curiously, compounds 1c and 1g, which are the most active against $T$. cruzi trypomastigotes $\left(\mathrm{IC}_{50} \mathrm{~S}=3.8\right.$ and $3.4 \mu \mathrm{M}$, respectively), did not present high inhibitory activity against cruzain, indicating that their anti-parasite activity occurs through a different target.

As proposed by Du et al. [17], the thioamide moiety has an
Table 2

Inhibitory activity in vitro of inhibitory activity against the cysteine protease cruzain of Trypanosoma cruzi.

\begin{tabular}{lllll}
\hline Cpd. & R1 & \% 2 & \% of inhibition ${ }^{\mathrm{a}}$ & $\mathrm{IC}_{50}(\mu \mathrm{M}) \pm \mathrm{SEM}^{\mathrm{b}}$ \\
\hline & & & \\
\end{tabular}

${ }^{\text {a }}$ Compounds were tested at $100 \mu \mathrm{M}(3 \mathbf{c}), 200 \mu \mathrm{M}(\mathbf{2}, \mathbf{2 c}$ and $\mathbf{3})$ and $300 \mu \mathrm{M}(\mathbf{1}, \mathbf{1 a}$ $\mathbf{m}$ ) and the percent inhibition of catalytic activity was determined.

b IC50 values $(\mu \mathrm{M})$ represent the mean \pm standard error of the mean (SEM) of three measurements.

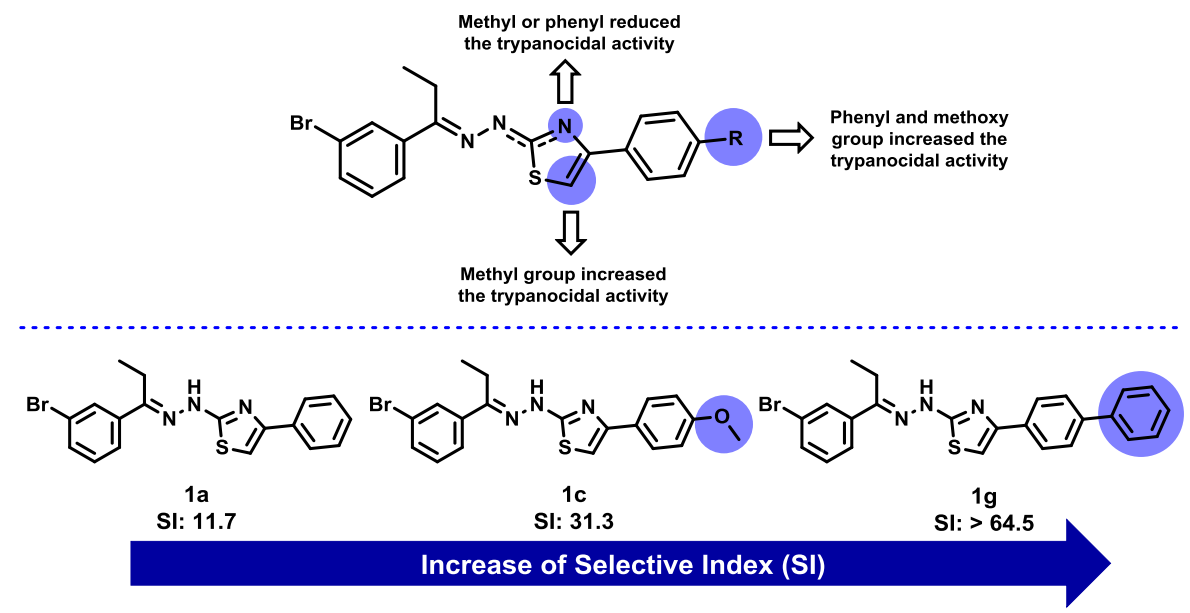

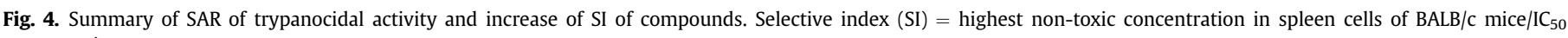
trypomastigotes. 
important role in the cruzain inhibition mechanism, however it has been demonstrated that cyclic derivatives, as 1,3-thiazoles [31], 2thiazolidin-4-ones [27] and 2,4-oxadiazoles [13], may also inhibit this enzyme. In this work, most cyclic derivatives present only modest inhibitory activity of cruzain and none of them were most potent than lead thiosemicarbazone $\mathbf{1}$, however, the most active compounds for tripomastigote form (1c and 19) did not present inhibitory activity of cruzain, indicating that cyclic derivatives may act by different paths in the parasite.

\subsection{Docking studies}

To define the structural determinants for cruzain inhibition, and in order to understand the mode of binding in such compounds, their interactions with cruzain (PDB ID: 3IUT) were investigated by docking studies. The binding modes were determined as the highest (most negative) score among the possible solutions for each ligand. Fig. 5 shows the superposition of the best docking solutions for compounds (1a,b, 1d,e and $\mathbf{1 h}-\mathbf{m}$ ), which have $\mathrm{IC}_{50}$ values experimentally available for inhibition against the cruzain target. The respective Autodock score values for compounds 1a-1b, 1d-e and $\mathbf{1 h}-\mathbf{m}$, are $-8.59,-8.76,-6.86,-7.46,-7.99,-7.52,-7.15$, $-8.29,-8.24$ and $-8.53 \mathrm{kcal} / \mathrm{mol}$, respectively.

In order to identify the molecular reasons for high affinities towards the cruzain target, it was selected the compound with the highest potency, $11\left(\mathrm{IC}_{50}=0.51 \pm 0.02 \mu \mathrm{M}\right)$, in addition the one which presents one of the lowest inhibitions, 1d $\left(\mathrm{IC}_{50}=16.5 \pm 0.3 \mu \mathrm{M}\right)$. Additionally, compound 1d presents the lowest inhibition $\left(\mathrm{IC}_{50}=146.05 \mu \mathrm{M}\right)$ when tested against the trypomastigotes forms of $T$. cruzi Y strains (see Table 1). A detailed analysis of the intermolecular interactions observed in the docking solutions was performed for these molecules. The differences between these two compounds are: (i) the presence of a 4fluorphenyl linked to the thiazole ring of molecule 1d, instead of a phenyl in molecule 11; (ii) a methyl group linked to thiazole ring in molecule 11, rather than a hydrogen atom, for molecule 1d.

The difference between the binding modes of these two molecules is show in detail in Fig. 6 and Table 3. It was found a $\pi-\pi$ Tshaped interaction for molecule $\mathbf{1 1}$ and a $\pi-\pi$ interaction for $\mathbf{1 d}$. The hydrogen bond found for $\mathbf{1 1}$, with the residue CYS25, is shorter $(2.14 \AA)$ and stronger than the hydrogen bond found for molecule 1d $(2.26 \AA)$ with the residue TRP184. It was also found a weak polar interaction (data not shown) for molecule 11, with the CYS25

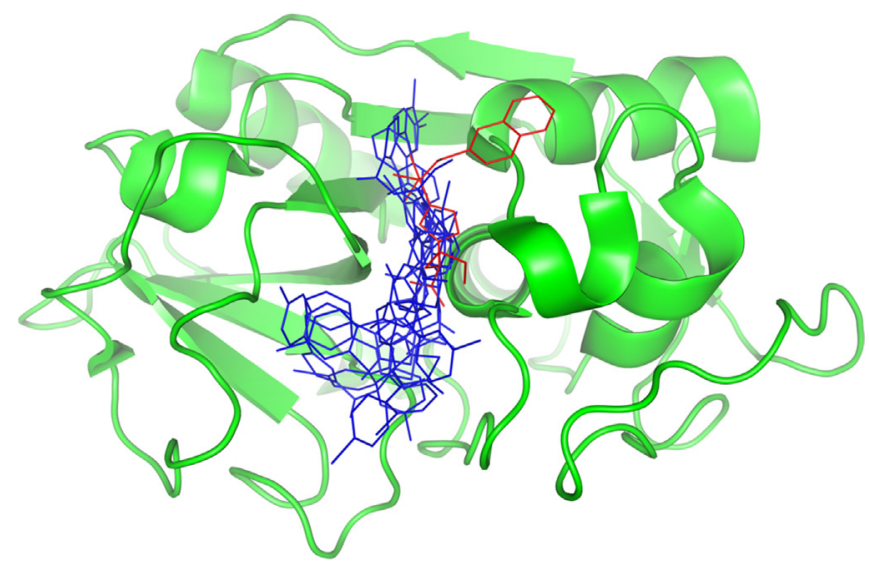

Fig. 5. Superposition of the docking solutions for compounds $\mathbf{1 a - 1 b}, \mathbf{1 d}-\mathbf{e}$ and $\mathbf{1 h}-\mathbf{m}$ (blue), bound to T. cruzi cruzain (green), besides the experimental position of the KB2 co-crystallized ligand (red). (For interpretation of the references to color in this figure legend, the reader is referred to the web version of this article.) residue $(2.68 \AA)$ of cruzain. These different intermolecular interactions are responsible for the greater stability of the complex formed with 11 than 1d, with docking scores of -8.24 and $-6.86 \mathrm{kcal} / \mathrm{mol}$, respectively. These findings corroborate with the in vitro inhibition potency measured for cruzain target.

\subsection{Ultrastructural studies}

To investigate the parasite morphological alterations caused by compound 1c, one of the most potent compounds tested IC $_{50}$ of $3.84 \mu \mathrm{M})$, its effects were evaluated at the ultrastructural level. The ultrastructural effects of 1c on trypomastigotes after $24 \mathrm{~h}$ were analyzed by Transmission Electron Microscopy (TEM) and Scanning Electron Microscopy (SEM), in concentrations corresponding to once or twice the $\mathrm{IC}_{50}$ value ( 3.4 and $6.8 \mu \mathrm{M}$ ) (Table 1$)$, and revealed several morphological alterations (Fig. 7).

The control group analyzed by SEM showed typical morphology with elongated body (Fig. 7A), whereas the group treated with 1c showed contortion of the parasite body with presence of blebs and alteration in morphology and size of the flagellum which also presented blebs (Fig. 7B).

The control group analyzed by TEM showed normal
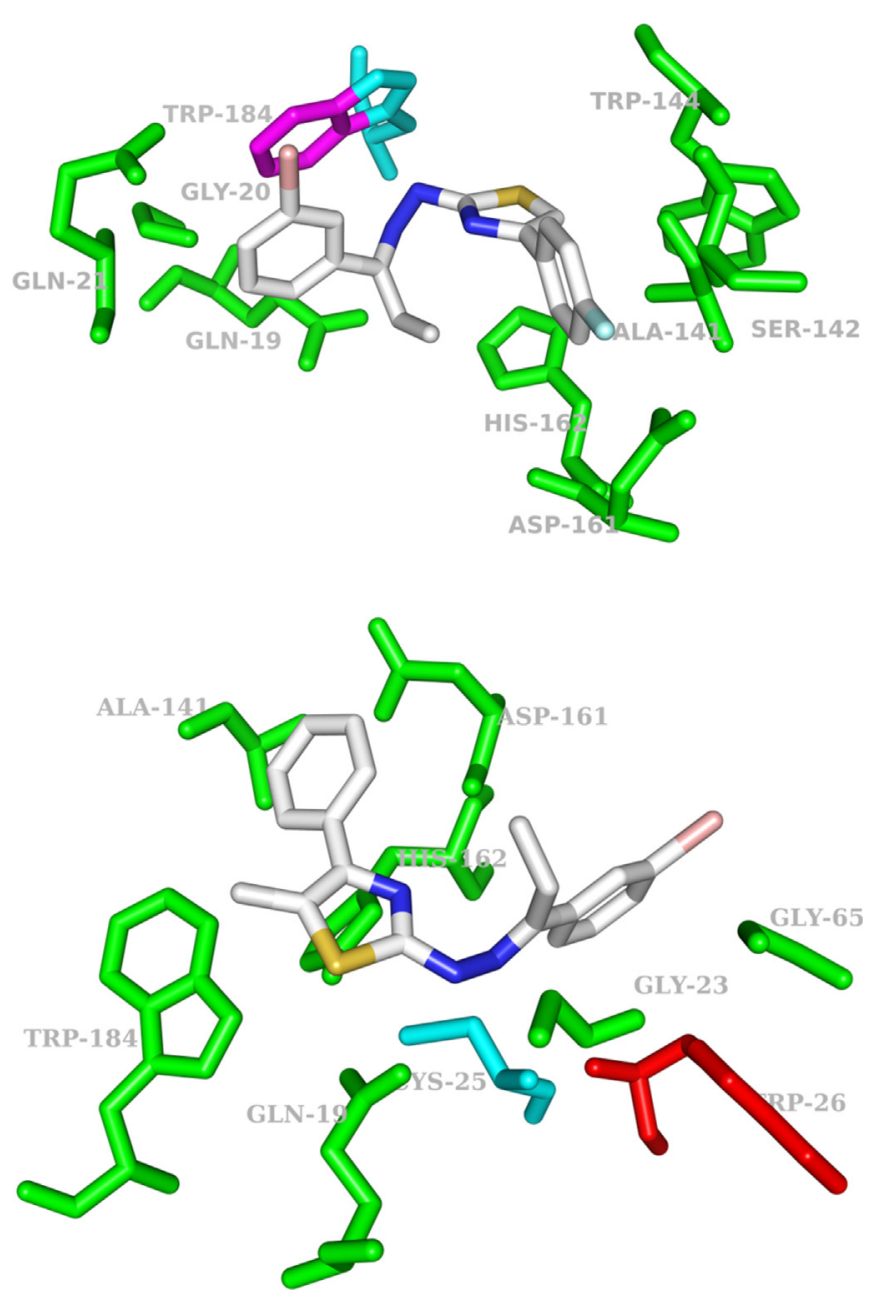

Fig. 6. Detailed view of the docking solutions for compound $\mathbf{1 d}$ (above) and $\mathbf{1 1}$ (below) The cruzain's residues forming hydrophobic contacts (HC) are colored in green, residues forming hydrogen bonds are colored in blue, residues forming $\pi-\pi$ T-shaped are colored in red, and residues forming $\pi-\pi$ interactions are colored in margenta. (For interpretation of the references to color in this figure legend, the reader is referred to the web version of this article.) 
Table 3

Molecular interactions between the cruzain target and molecules $\mathbf{1 d}$ and $\mathbf{1 1}$.

\begin{tabular}{lll}
\hline Residues (cruzain) & \multicolumn{2}{l}{ Molecular interactions } \\
\cline { 2 - 3 } & $1 \mathrm{~d}$ & $1 \mathrm{l}$ \\
\hline GLN19 & $\mathrm{HC}$ & $\mathrm{HC}$ \\
GLY20 & $\mathrm{HC}$ & - \\
GLN21 & $\mathrm{HC}$ & - \\
GLY23 & - & $\mathrm{HC}$ \\
CYS25 & - & 2.14 \\
TRP26 & - & $\mathrm{PIT}$ \\
GLY65 & - & $\mathrm{HC}$ \\
ALA141 & $\mathrm{HC}$ & $\mathrm{HC}$ \\
SER142 & $\mathrm{HC}$ & - \\
TRP144 & $\mathrm{HC}$ & - \\
ASP161 & $\mathrm{HC}$ & $\mathrm{HC}$ \\
HIS162 & $\mathrm{HC}$ & $\mathrm{HC}$ \\
TRP184 & 2.26 and PI & $\mathrm{HC}$ \\
Autodock Score & -6.86 & -8.24 \\
\hline
\end{tabular}

$\mathrm{HC}=$ hydrophobic contacts. PIT $=\pi-\pi$ T-shaped interaction. $\mathrm{HB}=$ Hydrogen bond with distances $[\AA ̊]$ between donor and acceptor. PI $=\pi-\pi$ interactions. Autodock Score in $\mathrm{kcal} / \mathrm{mol}$.

ultrastructural morphology of organelles such as kinetoplast, nucleus, nucleolus, flagellum, ribosomes and microtubules membrane (Fig. 7E). The groups treated with 1c analyzed showed intense cytosolic vacuolization, formation of blebs in the membrane, alterations in the reservosomes, swelling of the mitochondrion and abnormal chromatin condensation (Fig. 7G and $\mathrm{H}$ ). At the highest compound concentration $(6.8 \mu \mathrm{M})$ these alterations were emphasized, and alterations of the parasite morphology were induced. Furthermore, the cytosolic vacuolization was significantly more intense, indicating a dose-dependent action of compound 1c (Fig. 7G and $\mathrm{H}$ ).

Mitochondrial swelling had already been observed upon treatment with various compounds [33,37,38] and published data demonstrate that $T$. cruzi mitochondrial membranes, in contrast to those of vertebrate cells, are rich in endogenous parasite sterols, which are thought to be required for their energy transducing activities, being an important action target [34].

The intense cytoplasmic vacuolization observed (Fig. 7G and $\mathrm{H}$ ), has also been reported in the study of several other compounds described in literature [38-40]. Braga et al. [39] reports that under stress conditions, the cell reacts developing a contractile vacuole. Alterations in the reservosomes could also be important in growth inhibition, since they are involved in endocytosis, storage and breakdown of nutrients and could hamper the proliferation process of the parasite [38]. Observation of alterations in the nucleus can also indicate an effect on parasite proliferation [33].

\section{Conclusions}

New 3-(bromopropiophenone)hydrazinyl-1,3-thiazoles were prepared from the reaction between 3-(bromopropiophenone)thiosemicarbazone and $\alpha$-haloketones. The in vitro bioassay showed that compounds possess substantial antiparasitic activity against the trypomastigote form of $T$. cruzi. Most compounds were characterized as cruzain inhibitors. However, some of the most potent trypanocidal compounds did not inhibit this enzyme indicating that other targets are probably important to kill the parasite. The derivatives $\mathbf{1 c}$ and $\mathbf{1 g}$ exhibited improved selectivity for parasites when compared to the reference drug benznidazole. Ultrastructural analysis showed that the compound 1c caused irreversible lesions and changes in parasite morphology in a dosedependent manner. Our results pointed out the importance of 1,3thiazoles core as building-blocks for lead generation and showed that adjustment of conformational flexibility could represent a key event to be explored in the future.

\section{Experimental section}

\subsection{Chemistry}

Reagents were purchased from Acros Organics, Fluka, SigmaAldrich or Vetec and solvents from Vetec or Dinâmica. The deuterated solvents (DMSO- $d_{6}, \mathrm{CDCl}_{3}, \mathrm{D}_{2} \mathrm{O}$ ) were of the CIL brand (Tédia Brazil). The reactions were monitored in thin layer chromatography (TLC) using silica gel 60 containing fluorescent indicator $F_{254}$. The chromatographic plates were visualized under UV light (at dual wavelength 365 or $254 \mathrm{~nm}$ ). Melting points were measured using a capillary Thomas Hoover apparatus and the values $\left({ }^{\circ} \mathrm{C}\right)$ were not subsequently corrected. For all novel compounds, ${ }^{1} \mathrm{H}$ and ${ }^{13} \mathrm{C}$ NMR analyses were performed, and, when necessary, two-dimensional analysis (DEPT) as well as the addition of $\mathrm{D}_{2} \mathrm{O}$ for locating $\mathrm{NH}$ signals. All compounds were solubilized in DMSO- $d_{6}$. The ${ }^{1} \mathrm{H}$ and ${ }^{13} \mathrm{C}$ NMR spectra were obtained using Unity Plus model Varian instruments $\left(400 \mathrm{MHz}\right.$ for ${ }^{1} \mathrm{H}, 100 \mathrm{MHz}$ for ${ }^{13} \mathrm{C}$ ) or Bruker AMX (300 MHz for ${ }^{1} \mathrm{H}, 75.5 \mathrm{MHz}$ for ${ }^{13} \mathrm{C}$ ), using tetramethylsilane (tms) as internal standard. The number of signals in the ${ }^{1} \mathrm{H}$ NMR spectra were designated as follows: s/singlet;/ $\mathrm{d}$ doublet, $\mathrm{t} /$ triplet, $\mathrm{dd} /$ double doublet, q/quartet, $\mathrm{m} /$ multiplet and the coupling constants, in hertz, as J. Infrared spectroscopy was performed on a Bruker instrument (model IFS 66) using KBr pellets.

\subsubsection{General procedure for synthesis of compounds 1, 2 and 3}

In a round bottom flask of $100 \mathrm{~mL}, 1$-(3-bromophenyl)propan-1one $(5.5 \mathrm{mmol})$ and the respective thiosemicarbazide $(5.5 \mathrm{mmol})$ were dissolved in ethanol $(20 \mathrm{~mL})$ and $\mathrm{HCl}$ (cat.). The mixture was maintained under magnetic stirring and heating reflux for $2-3 \mathrm{~h}$. The reaction was monitored by thin-layer chromatographic plate (TLC). The resulting solid was filtered through a sintered funnel and washed with ethanol to yield pure product.

4.1.1.1. (E)-2-[1-(3-bromophenyl)propylidene]hydrazinecarbothioamide (1). 90\%yield; $\mathrm{mp}\left({ }^{\circ} \mathrm{C}\right): 144-146 ; \mathrm{IR}\left(\mathrm{KBr}, \mathrm{cm}^{-1}\right) 3415.33(\mathrm{NH})$, $1507.11(\mathrm{C}=\mathrm{N}) ;{ }^{1} \mathrm{H}$ NMR $\left(\mathrm{DMSO}-d_{6}, 300 \mathrm{MHz}\right) \delta \mathrm{ppm}: 0.99(\mathrm{t}, 3 \mathrm{H}$, $\left.J=7.4 \mathrm{~Hz}, \mathrm{CH}_{3}\right), 2.86\left(\mathrm{q}, 2 \mathrm{H}, J=7.6 \mathrm{~Hz}, \mathrm{CH}_{2}\right), 7.34(\mathrm{t}, 1 \mathrm{H}, J=8.0 \mathrm{~Hz}$, $\mathrm{Ar}), 7.56(\mathrm{~d}, 1 \mathrm{H}, J=8.0 \mathrm{~Hz}, \mathrm{Ar}), 7.86(\mathrm{~d}, 1 \mathrm{H}, J=7.6 \mathrm{~Hz}, \mathrm{Ar}), 8.08$ and $8.15\left(2 \mathrm{~s}, 2 \mathrm{H}, \mathrm{NH}_{2}\right), 8.31$ (s, $\left.1 \mathrm{H}, \mathrm{Ar}\right), 10.35(\mathrm{~s}, 1 \mathrm{H}, \mathrm{NH}) ;{ }^{13} \mathrm{C} \mathrm{NMR}$ (DMSO- $\left.d_{6}, 75.5 \mathrm{MHz}\right) \delta$ ppm: $10.8\left(\mathrm{CH}_{3}\right), 19.1\left(\mathrm{CH}_{2}\right), 122.1(\mathrm{Ar}), 125.7$ ( $\mathrm{Ar}), 129.0$ ( $\mathrm{Ar}), 130.4(\mathrm{Ar}), 131.8(\mathrm{Ar}), 138.8(\mathrm{Ar}), 150.2(\mathrm{C}=\mathrm{N}), 179.0$ $(\mathrm{C}=\mathrm{S})$. Anal. Calcd for $\mathrm{C}_{10} \mathrm{H}_{12} \mathrm{BrN}_{3} \mathrm{~S}: \mathrm{C}, 41.97 ; \mathrm{H}, 4.23 ; \mathrm{N}, 14.68 ; \mathrm{S}$, 11.20. found: C, 41.93; H, 4.26; N, 14.62; S, 11.27. HRMS: 284.9940 $[\mathrm{M}+\mathrm{H}]^{+}$.

4.1.1.2. (E)-2-[1-(3-bromophenyl)propylidene]-N-methylhydrazinecarbothioamide (2). 89\% yield; $\mathrm{mp}\left({ }^{\circ} \mathrm{C}\right)$ : $148-150$; IR ( $\mathrm{KBr}$, $\left.\mathrm{cm}^{-1}\right): 1552.22(\mathrm{C}=\mathrm{N}) ;{ }^{1} \mathrm{H}$ NMR (DMSO- $\left.d_{6}, 300 \mathrm{MHz}\right) \delta_{\mathrm{ppm}}: 1.21(\mathrm{t}$, $\left.J=7.6 \mathrm{~Hz}, 3 \mathrm{H}, \mathrm{CH}_{3}\right), 2.69\left(\mathrm{q}, J=7.6 \mathrm{~Hz}, 2 \mathrm{H}, \mathrm{CH}_{2}\right), 3.29\left(\mathrm{~d}, 3 \mathrm{H}, \mathrm{CH}_{3}\right)$, $7.29(\mathrm{t}, J=7.8 \mathrm{~Hz}, 1 \mathrm{H}, \mathrm{Ar}), 7.53(\mathrm{~d}, J=7.8 \mathrm{~Hz}, 1 \mathrm{H}, \mathrm{Ar}), 7.60(\mathrm{~d}$, $J=7.8 \mathrm{~Hz}, 1 \mathrm{H}, \mathrm{Ar}), 7.84$ (s, 1H, Ar), $8.42(\mathrm{~s}, 1 \mathrm{H}, \mathrm{NH}), 8.81(\mathrm{~s}, 1 \mathrm{H}, \mathrm{NH})$; ${ }^{13} \mathrm{C}$ NMR (DMSO-d, $\left.75.5 \mathrm{MHz}\right) \delta \mathrm{ppm}: 10.4\left(\mathrm{CH}_{3}\right), 20.1\left(\mathrm{CH}_{2}\right), 31.4$ $\left(\mathrm{CH}_{3}\right), 122.9(\mathrm{Ar}), 124.9(\mathrm{Ar}), 129.2(\mathrm{Ar}), 130.1(\mathrm{Ar}), 132.5(\mathrm{Ar}), 138.4$ (Ar), $149.9(\mathrm{C}=\mathrm{N}), 178.9(\mathrm{C}=\mathrm{S})$. Anal. Calcd for $\mathrm{C}_{11} \mathrm{H}_{14} \mathrm{BrN}_{3} \mathrm{~S}$ : C, 44.01; H, 4.70; N, 14.00; S, 10.68. found: C, 43.93; H, 4.84; N, 14.02; S, 9.83. HRMS: $300.0316[\mathrm{M}+\mathrm{H}]^{+}$.

4.1.1.3. (E)-2-[1-(3-bromophenyl)propylidene]-N-phenylhydrazinecarbothioamide (3). $87 \%$ yield; $\mathrm{mp}\left({ }^{\circ} \mathrm{C}\right)$ : $169-173$; IR $(\mathrm{KBr}$, $\left.\mathrm{cm}^{-1}\right): 1588.14(\mathrm{C}=\mathrm{N}) ;{ }^{1} \mathrm{H}$ NMR $\left(\mathrm{DMSO}-d_{6}, 300 \mathrm{MHz}\right) \delta_{\mathrm{ppm}}: 1.05(\mathrm{t}$, $\left.J=7.5 \mathrm{~Hz}, 3 \mathrm{H}, \mathrm{CH}_{3}\right), 2.94\left(\mathrm{q}, J=7.5 \mathrm{~Hz}, 2 \mathrm{H}, \mathrm{CH}_{2}\right), 7.22(\mathrm{t}, J=7.5 \mathrm{~Hz}$, $1 \mathrm{H}, \mathrm{Ar}), 7.35-7.61(\mathrm{~m}, 6 \mathrm{H}, \mathrm{Ar}), 7.95(\mathrm{~d}, J=8.1 \mathrm{~Hz}, 1 \mathrm{H}, \mathrm{Ar}), 8.21(\mathrm{~s}, 1 \mathrm{H}$, 

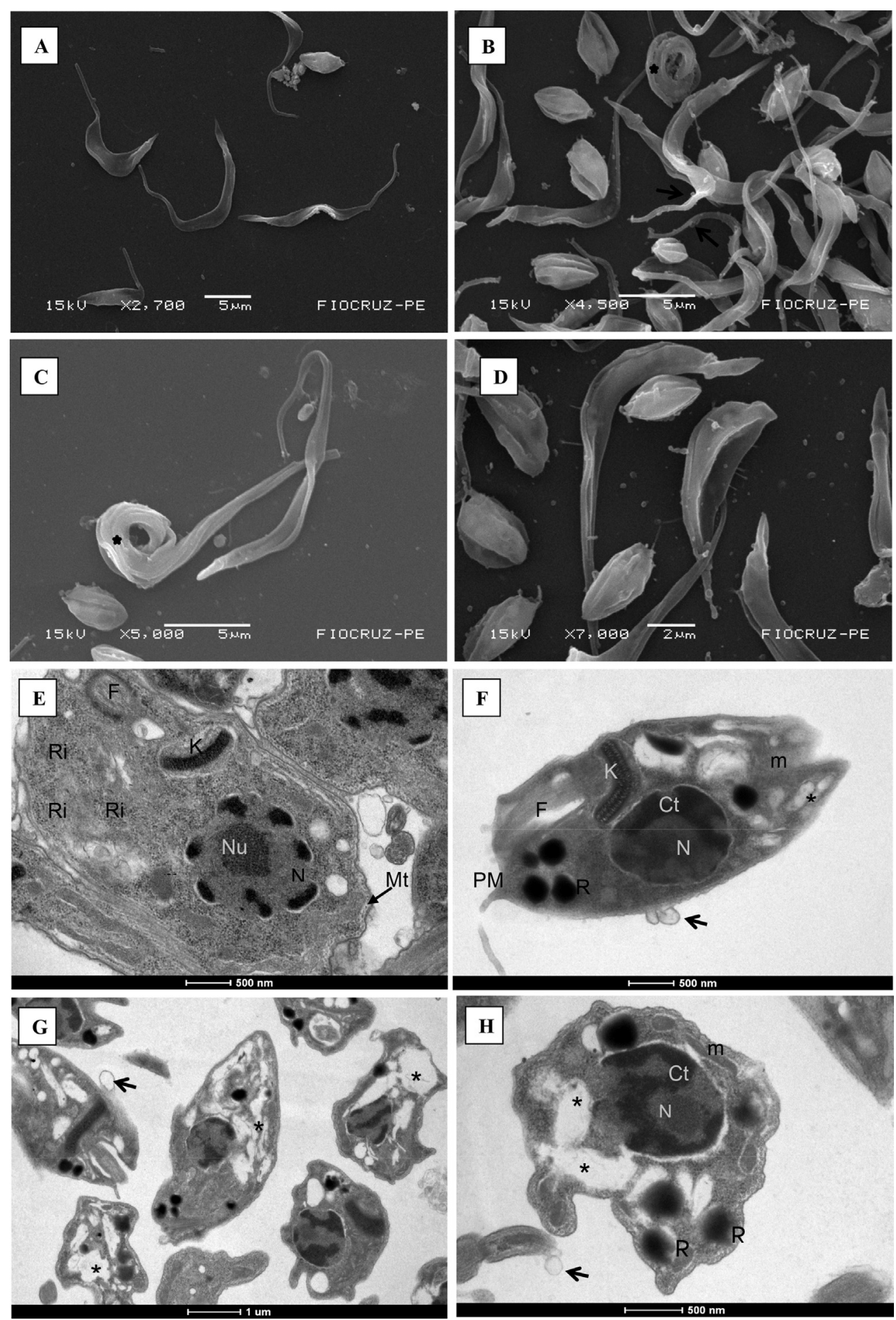

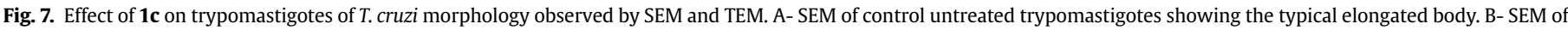

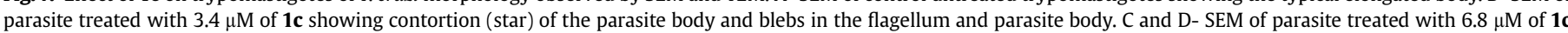

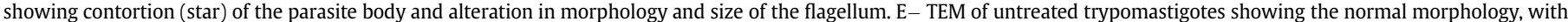

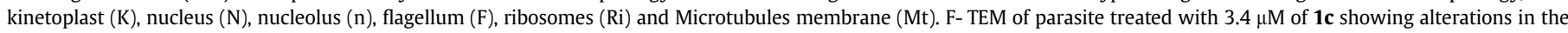

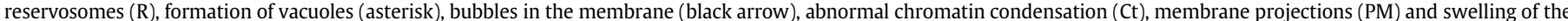

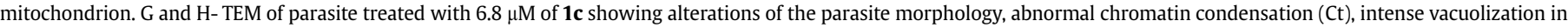
the cytoplasm (asterisk), swelling of the mitochondrion, bubbles in the membrane (black arrow) and alterations in the reservosomes (R).

Ar), $10.15(\mathrm{~s}, 1 \mathrm{H}, \mathrm{NH}), 10.76(\mathrm{~s}, 1 \mathrm{H}, \mathrm{NH}) ;{ }^{13} \mathrm{C}$ NMR (DMSO-d $75.5 \mathrm{MHz}) \delta$ ppm: $10.9\left(\mathrm{CH}_{3}\right), 19.5\left(\mathrm{CH}_{2}\right), 122.1(\mathrm{Ar}), 125.5(\mathrm{Ar}), 126.1$ (Ar), 126.3 (Ar), 128.1 (Ar), 129.3 (Ar), 130.4 (Ar), 132.0 (Ar), 138.7 (Ar), $139.2(\mathrm{Ar}), 151.1(\mathrm{C}=\mathrm{N}), 177.3(\mathrm{C}=\mathrm{S})$. Anal. Calcd for
$\mathrm{C}_{16} \mathrm{H}_{16} \mathrm{BrN}_{3} \mathrm{~S}: \mathrm{C}, 53.04 ; \mathrm{H}, 4.45 ; \mathrm{N}, 11.60 ; \mathrm{S}, 8.85$. found: $\mathrm{C}, 52.93 ; \mathrm{H}$, 4.39; N, 11.56; S, 8.79. HRMS: $361.0602[\mathrm{M}+\mathrm{H}]^{+}$. 
4.1.2. General procedure for synthesis of the series (1a-3c)

In round bottom flask, aryl thiosemicarbazone $(1,2$ or 3$)$ and the respective 2-bromoacetophenone were dissolved in 2-propanol $(20 \mathrm{~mL})$. The reaction mixture was kept at room temperature for $1 \mathrm{~h}$. The reactions were monitored by thin-layer chromatographic plate (TLC). The resulting solid was filtered through sintered funnel with distilled water, yielding the pure product.

4.1.2.1. (E)-2-\{2-[1-(3-bromophenyl)propylidene]hydrazinyl\}-4phenylthiazole (1a). $72 \%$ yield; $\mathrm{mp}\left({ }^{\circ} \mathrm{C}\right)$ : $196-199 ; \mathrm{IR}\left(\mathrm{KBr}, \mathrm{cm}^{-1}\right)$ : $1516.36(\mathrm{C}=\mathrm{N}) ;{ }^{1} \mathrm{H}$ NMR (DMSO- $\left.d_{6}, 300 \mathrm{MHz}\right) \delta \mathrm{ppm}: 1.03(\mathrm{t}$, $\left.J=6.8 \mathrm{~Hz}, 3 \mathrm{H}, \mathrm{CH}_{3}\right), 2.82\left(\mathrm{~d}, J=7.2 \mathrm{~Hz}, 2 \mathrm{H}, \mathrm{CH}_{2}\right), 7.28-7.39(\mathrm{~m}, 5 \mathrm{H}$, Ar), 7.53 (d, $J=7.2 \mathrm{~Hz}, 1 \mathrm{H}, \mathrm{Ar}), 7.73(\mathrm{~d}, J=7.2 \mathrm{~Hz}, 1 \mathrm{H}, \mathrm{Ar}), 7.82$ (d, $J=7.2 \mathrm{~Hz}, 2 \mathrm{H}, \mathrm{Ar}), 7.91$ (s, 1H, thiazole $), 10.64(\mathrm{~s}, 1 \mathrm{H}, \mathrm{NH}) ;{ }^{13} \mathrm{C} \mathrm{NMR}$ $\left(\right.$ DMSO- $\left.d_{6}, 75.5 \mathrm{MHz}\right) \delta \mathrm{ppm}: 10.1\left(\mathrm{CH}_{3}\right), 19.6\left(\mathrm{CH}_{2}\right), 104.4(\mathrm{CH}$, thiazole), 122.1 ( $\mathrm{Ar}), 124.9(\mathrm{Ar}), 125.6(\mathrm{Ar}), 127.8(\mathrm{Ar}), 127.9$ (Ar), 128.2 (Ar), $128.6(\mathrm{Ar}), 130.7(\mathrm{Ar}), 131.4(\mathrm{Ar}), 134.0(\mathrm{Ar}), 138.9(\mathrm{C}-\mathrm{N}$, thiazole), $149.8(\mathrm{C}=\mathrm{N}), 169.6(\mathrm{~S}-\mathrm{C}=\mathrm{N}$, thiazole). Anal. Calcd for $\mathrm{C}_{18} \mathrm{H}_{16} \mathrm{BrN}_{3} \mathrm{~S}$ : C, 55.96; $\mathrm{H}, 4.17 ; \mathrm{N}, 10.88 ; \mathrm{S}, 8.30$. found: $\mathrm{C}, 56.02 ; \mathrm{H}$, 4.14; N, 10.83; S, 8.27. HRMS: $387.1737[\mathrm{M}+\mathrm{H}]^{+}$.

4.1.2.2. (E)-2-\{2-[1-(3-bromophenyl)propylidene]hydrazinyl $\}-4-p-$ tolylthiazole $(1 \mathrm{~b}) .69 \%$ yield; $\mathrm{mp}\left({ }^{\circ} \mathrm{C}\right)$ : $192-196$; $\mathrm{IR}\left(\mathrm{KBr}, \mathrm{cm}^{-1}\right)$ : $1505.60(\mathrm{C}=\mathrm{N}) ;{ }^{1} \mathrm{H}$ NMR (DMSO- $\left.d_{6}, 300 \mathrm{MHz}\right) \delta \mathrm{ppm}: 1.06(\mathrm{~s}, 3 \mathrm{H}$, $\left.\mathrm{CH}_{3}\right), 2.31\left(\mathrm{~s}, 3 \mathrm{H}, \mathrm{CH}_{3}\right), 2.86\left(\mathrm{~d}, J=6.8 \mathrm{~Hz}, 2 \mathrm{H}, \mathrm{CH}_{2}\right), 6.32(\mathrm{~s}, 1 \mathrm{H}, \mathrm{NH})$, 7.21-7.75 (m, 8H, Ar), 7.94 (s, $1 \mathrm{H}$, thiazole); ${ }^{13} \mathrm{C}$ NMR (DMSO- $d_{6}$, $75.5 \mathrm{MHz}) \delta \mathrm{ppm}: 10.6\left(\mathrm{CH}_{3}\right), 19.6\left(\mathrm{CH}_{3}\right), 20.8\left(\mathrm{CH}_{2}\right), 103.4(\mathrm{CH}$, thiazole), 122.1 ( $\mathrm{Ar}), 124.8$ ( $\mathrm{Ar}), 125.6$ ( $\mathrm{Ar}), 127.8(\mathrm{Ar}), 128.2$ ( $\mathrm{Ar})$, 129.2 (Ar), 130.7 (Ar), 131.3 (Ar), 134.0 (Ar), 137.0 (Ar), 138.9 (C-N, thiazole), $149.0(\mathrm{C}=\mathrm{N}), 169.5(\mathrm{~S}-\mathrm{C}=\mathrm{N}$, thiazole). Anal. Calcd for $\mathrm{C}_{19} \mathrm{H}_{18} \mathrm{BrN}_{3} \mathrm{~S}$ : C, 57.00; $\mathrm{H}, 4.53 ; \mathrm{N}, 10.50 ; \mathrm{S}, 8.01$. found: $\mathrm{C}, 57.07 ; \mathrm{H}$, 4.58; N, 10.48; S, 8.05. HRMS: $399.1896[\mathrm{M}+\mathrm{H}]^{+}$.

4.1.2.3. (E)-2-\{2-[1-(3-bromophenyl)propylidene]hydrazinyl $\}-4-(4-$ methoxyphenyl)thiazole (1c). 62\% yield; $\mathrm{mp}\left({ }^{\circ} \mathrm{C}\right)$ : $197-200 ; \mathrm{IR}(\mathrm{KBr}$, $\left.\mathrm{cm}^{-1}\right)$ : $3115.41(\mathrm{NH}), 2954.46$ and 2831.76 $(\mathrm{CH} \mathrm{Ar}), 1509.43(\mathrm{C}=\mathrm{N})$; ${ }^{1} \mathrm{H}$ NMR (DMSO- $\left.d_{6}, 300 \mathrm{MHz}\right) \delta \mathrm{ppm}: 1.06\left(\mathrm{t}, J=7.3 \mathrm{~Hz}, 3 \mathrm{H}, \mathrm{CH}_{3}\right.$ ), $2.78\left(\mathrm{q}, J=7.5 \mathrm{~Hz}, 2 \mathrm{H}, \mathrm{CH}_{2}\right), 3.78\left(\mathrm{~s}, 3 \mathrm{H}, \mathrm{CH}_{3}\right), 5.71(\mathrm{~s}, 1 \mathrm{H}, \mathrm{NH}), 6.98$ (d, $J=8.7 \mathrm{~Hz}, 2 \mathrm{H}, \mathrm{Ar}), 7.16(\mathrm{~s}, 1 \mathrm{H}, \mathrm{Ar}), 7.39(\mathrm{t}, J=7.8 \mathrm{~Hz}, 1 \mathrm{H}, \mathrm{Ar}), 7.57$ $(\mathrm{dd}, J=8.1 \mathrm{~Hz}, 1 \mathrm{H}, \mathrm{Ar}), 7.78(\mathrm{~d}, J=7.8 \mathrm{~Hz}, 1 \mathrm{H}, \mathrm{Ar}), 7.79(\mathrm{~d}, J=8.4 \mathrm{~Hz}$, $2 \mathrm{H}, \mathrm{Ar}$ ), 7.95 (s, $1 \mathrm{H}$, thiazole); ${ }^{13} \mathrm{C}$ NMR (DMSO-d $\left.d_{6}, 75.5 \mathrm{MHz}\right) \delta_{\mathrm{ppm}}$ : $10.7\left(\mathrm{CH}_{3}\right), 19.6\left(\mathrm{CH}_{2}\right), 55.2\left(\mathrm{CH}_{3}\right), 102.3(\mathrm{CH}$, thiazole $), 114.0(\mathrm{Ar})$, 122.2 ( $\mathrm{Ar}), 124.9(\mathrm{Ar}), 125.6(\mathrm{Ar}), 127.0(\mathrm{Ar}), 127.9(\mathrm{Ar}), 128.2(\mathrm{Ar})$, 130.8 (Ar), $131.4(\mathrm{Ar}), 137.0(\mathrm{Ar}), 139.0(\mathrm{C}-\mathrm{N}$, thiazole $), 158.9(\mathrm{C}=\mathrm{N})$, $169.5\left(\mathrm{~S}-\mathrm{C}=\mathrm{N}\right.$, thiazole). Anal. Calcd for $\mathrm{C}_{19} \mathrm{H}_{18} \mathrm{BrN}_{3} \mathrm{OS}$ : $\mathrm{C}, 54.81 ; \mathrm{H}$, 4.36; N, 10.09; O, 3.84; S, 7.70. found: C, 54.96; H, 4.20; N, 10.02; S, 7.74. HRMS: $414.8419[\mathrm{M}-\mathrm{H}]^{-}$.

4.1.2.4. (E)-2-\{2-[1-(3-bromophenyl)propylidene $]$ hydrazinyl $\}-4-(4-$ fluorophenyl)thiazole (1d). 65\% yield; $\mathrm{mp}\left({ }^{\circ} \mathrm{C}\right)$ : 207-210; IR ( $\mathrm{KBr}$, $\left.\mathrm{cm}^{-1}\right): 1509.35(\mathrm{C}=\mathrm{N}) ;{ }^{1} \mathrm{H}$ NMR (DMSO- $\left.d_{6}, 300 \mathrm{MHz}\right) \delta_{\mathrm{ppm}}: 1.07(\mathrm{t}$, $\left.J=7.4 \mathrm{~Hz}, 3 \mathrm{H}, \mathrm{CH}_{3}\right), 2.85\left(\mathrm{q}, J=7.4 \mathrm{~Hz}, 2 \mathrm{H}, \mathrm{CH}_{2}\right), 4.28(\mathrm{~s}, 1 \mathrm{H}, \mathrm{NH})$, $7.22-7.93(\mathrm{~m}, 9 \mathrm{H}, \mathrm{Ar}) ;{ }^{13} \mathrm{C}$ NMR (DMSO- $\left.d_{6}, 75.5 \mathrm{MHz}\right) \delta \mathrm{ppm}: 10.6$ $\left(\mathrm{CH}_{3}\right), 19.5\left(\mathrm{CH}_{2}\right), 104.1$ ( $\mathrm{CH}$, thiazole), $115.3(\mathrm{Ar}), 115.6(\mathrm{Ar}), 122.1$ (Ar), 124.8 (Ar), 127.5 (Ar), $127.6(\mathrm{Ar}), 128.1$ (Ar), 129.2 (Ar), 130.7 (Ar), $131.3(\mathrm{Ar}), 139.1(\mathrm{C}-\mathrm{N}$, thiazole $), 149.2(\mathrm{C}=\mathrm{N}), 169.7(\mathrm{~S}-\mathrm{C}=\mathrm{N}$, thiazole). Anal. Calcd for $\mathrm{C}_{18} \mathrm{H}_{15} \mathrm{BrFN}_{3} \mathrm{~S}$ : C, 53.47; H, 3.74; N, 10.39; S, 7.93. found: C, 54.14; H, 3.69; N, 10.41; S, 7.98. HRMS: 404.0101 $[\mathrm{M}+\mathrm{H}]^{+}$.

4.1.2.5. (E)-2-\{2-[1-(3-bromophenyl)propylidene]hydrazinyl $\}-4-(4-$ chlorophenyl)thiazole (1e). 62\% yield; $\mathrm{mp}\left({ }^{\circ} \mathrm{C}\right)$ : 204-209; IR ( $\mathrm{KBr}$, $\mathrm{cm}^{-1}$ ): $3922.26(\mathrm{NH}) ;{ }^{1} \mathrm{H}$ NMR (DMSO-d, $\left.300 \mathrm{MHz}\right) \delta \mathrm{ppm}: 1.09(\mathrm{t}$, $\left.J=5.8 \mathrm{~Hz}, 3 \mathrm{H}, \mathrm{CH}_{3}\right), 2.83\left(\mathrm{q}, J=5.8 \mathrm{~Hz}, 2 \mathrm{H}, \mathrm{CH}_{2}\right), 6,01(\mathrm{~s}, 1 \mathrm{H}, \mathrm{NH})$, 7.36-7.93 (m, 9H, Ar); ${ }^{13} \mathrm{C}$ NMR (DMSO- $\left.d_{6}, 75.5 \mathrm{MHz}\right) \delta \mathrm{ppm}: 10.6$
$\left(\mathrm{CH}_{3}\right), 19.6\left(\mathrm{CH}_{2}\right), 105.2(\mathrm{CH}$, thiazole), 122.1 (Ar), 124.8 (Ar), 127.3 (Ar), 128.7 (Ar), 129.6 (Ar), 130.8 (Ar), 131.3 (Ar), 132.0 (Ar), 132.4 (Ar), $133.5(\mathrm{Ar}), 139.1(\mathrm{C}-\mathrm{N}$, thiazole $), 149.2(\mathrm{C}=\mathrm{N}), 169.8(\mathrm{~S}-\mathrm{C}=\mathrm{N}$, thiazole). Anal. Calcd for $\mathrm{C}_{18} \mathrm{H}_{15} \mathrm{BrClN}_{3} \mathrm{~S}$ : C, 51.38; H, 3.59; N, 9.99; S, 7.62. found: C, 52.04; H, 3.60; N, 9.97; S, 7.64. HRMS: 421.1562 $[\mathrm{M}+\mathrm{H}]^{+}$.

4.1.2.6. (E)-2-\{2-[1-(3-bromophenyl)propylidene]hydrazinyl\}-4-(4nitrophenyl)thiazole (1f). 63\% yield; $\mathrm{mp}\left({ }^{\circ} \mathrm{C}\right)$ : $193-196$; IR ( $\mathrm{KBr}$, $\left.\mathrm{cm}^{-1}\right): 3332.81(\mathrm{NH}), 1508.37(\mathrm{C}=\mathrm{N}) ;{ }^{1} \mathrm{H}$ NMR (DMSO-d $d_{6}$, $300 \mathrm{MHz}) \delta_{\mathrm{ppm}}: 1.07\left(\mathrm{t}, J=7.8 \mathrm{~Hz}, 3 \mathrm{H}, \mathrm{CH}_{3}\right), 2.86(\mathrm{q}, J=7.8 \mathrm{~Hz}, 2 \mathrm{H}$, $\left.\mathrm{CH}_{2}\right), 7.39-8.29(\mathrm{~m}, 9 \mathrm{H}, \mathrm{Ar}), 11.66(\mathrm{~s}, 1 \mathrm{H}, \mathrm{NH}) ;{ }^{13} \mathrm{C}$ NMR (DMSO-d $75.5 \mathrm{MHz}) \delta$ ppm: $10.5\left(\mathrm{CH}_{3}\right), 19.6\left(\mathrm{CH}_{2}\right), 109.2(\mathrm{CH}$, thiazole $), 122.1$ (Ar), 124.1 (Ar), 124.8 (Ar), 126.3 (Ar), 128.2 (Ar), 130.7 (Ar), 131.3 (Ar), 132.4 (Ar), 133.5 (Ar), 139.0 (Ar), 140.7 (C-N, thiazole), 146.2 $(\mathrm{C}=\mathrm{N}), 170.0(\mathrm{~S}-\mathrm{C}=\mathrm{N}$, thiazole $)$. Anal. Calcd for $\mathrm{C}_{18} \mathrm{H}_{15} \mathrm{BrN}_{4} \mathrm{O}_{2} \mathrm{~S}: \mathrm{C}$, $50.13 ; \mathrm{H}, 3.51 ; \mathrm{N}, 12.99 ; \mathrm{S}, 7.43$. found: C, 50.15; H, 3.55; N, 12.97; S, 7.39. HRMS: $430.9228[\mathrm{M}+\mathrm{H}]^{+}$.

4.1.2.7. (E)-4-(biphenyl-4-yl)-2-\{2-[1-(3-bromophenyl)propylidene] hydrazinyl thiazole (1 $\mathrm{g})$. 64\% yield; $\mathrm{mp}\left({ }^{\circ} \mathrm{C}\right)$ : $218-221$; IR ( $\mathrm{KBr}$, $\left.\mathrm{cm}^{-1}\right): 1611.72(\mathrm{C}=\mathrm{N}) ;{ }^{1} \mathrm{H}$ NMR (DMSO- $\left.d_{6}, 300 \mathrm{MHz}\right) \delta_{\mathrm{ppm}}: 1.29(\mathrm{t}$, $\left.J=7.8 \mathrm{~Hz}, 3 \mathrm{H}, \mathrm{CH}_{3}\right), 2.92\left(\mathrm{q}, J=7.8 \mathrm{~Hz}, 2 \mathrm{H}, \mathrm{CH}_{2}\right), 6.76(\mathrm{~s}, 1 \mathrm{H}$, Thiazole), 7.19-7.87 (m, 13H, Ar), 12.89 (s, 1H, NH); ${ }^{13} \mathrm{C}$ NMR (DMSO-d 6 , $75.5 \mathrm{MHz}) \delta \mathrm{ppm}: 11.1\left(\mathrm{CH}_{3}\right), 22.4\left(\mathrm{CH}_{2}\right), 101.1(\mathrm{CH}$, thiazole), $123.0(\mathrm{Ar}), 125.4(\mathrm{Ar}), 125.8(\mathrm{Ar}), 126.0(\mathrm{Ar}), 126.9(\mathrm{Ar})$, 128.1 ( $\mathrm{Ar}), 128.2$ (Ar), $128.9(\mathrm{Ar}), 129.7(\mathrm{Ar}), 130.2(\mathrm{Ar}), 133.5(\mathrm{Ar})$, $136.9(\mathrm{Ar}), 139.5(\mathrm{Ar}), 140.7(\mathrm{Ar}), 143.2(\mathrm{C}-\mathrm{N}$, thiazole $), 159.7(\mathrm{C}=\mathrm{N})$, $170.0\left(\mathrm{~S}-\mathrm{C}=\mathrm{N}\right.$, thiazole). Anal. Calcd for $\mathrm{C}_{24} \mathrm{H}_{20} \mathrm{BrN}_{3} \mathrm{~S}: \mathrm{C}, 62.34 ; \mathrm{H}$, 4.36; N, 9.09; S, 6.93. found: C, 62.35; H, 4.38; N, 9.07; S, 6.96. HRMS: $461.9808[\mathrm{M}+\mathrm{H}]^{+}$.

4.1.2.8. (E)-2-\{2-[1-(3-bromophenyl)propylidene]hydrazinyl $\}-4-(3-$ nitrophenyl)thiazole (1h). 64\% yield; $\mathrm{mp}\left({ }^{\circ} \mathrm{C}\right): 220-223$; IR ( $\mathrm{KBr}$, $\left.\mathrm{cm}^{-1}\right): 1530.66(\mathrm{C}=\mathrm{N}) ;{ }^{1} \mathrm{H}$ NMR (DMSO- $\left.d_{6}, 300 \mathrm{MHz}\right) \delta_{\mathrm{ppm}}: 1.07(\mathrm{t}$, $\left.J=7.8 \mathrm{~Hz}, 3 \mathrm{H}, \mathrm{CH}_{3}\right), 2.86\left(\mathrm{q}, J=7.8 \mathrm{~Hz}, 2 \mathrm{H}, \mathrm{CH}_{2}\right), 6.83(\mathrm{~s}, 1 \mathrm{H}, \mathrm{NH})$, 7.39-8.72 (m, 9H, Ar), $11.6(\mathrm{~s}, 1 \mathrm{H}, \mathrm{NH}) ;{ }^{13} \mathrm{C}$ NMR (DMSO-d $75.5 \mathrm{MHz}) \delta$ ppm: $10.5\left(\mathrm{CH}_{3}\right), 19.5\left(\mathrm{CH}_{2}\right), 107.1(\mathrm{CH}$, thiazole $), 120.0$ (Ar), 122.1 (Ar), 124.8 (Ar), 128.2 (Ar), 130.2 (Ar), 130.7 (Ar), 131.3 (Ar), 131.5 (Ar), 133.5 (Ar), 136.2 (Ar), 139.0 (Ar), 140.7 (Ar), 148.3 (C-N, thiazole), $149.3(\mathrm{C}=\mathrm{N}), 169.9(\mathrm{~S}-\mathrm{C}=\mathrm{N}$, thiazole $)$. Anal. Calcd for $\mathrm{C}_{18} \mathrm{H}_{15} \mathrm{BrN}_{4} \mathrm{O}_{2} \mathrm{~S}$ : C, 50.13; $\mathrm{H}, 3.51 ; \mathrm{N}, 12.99 ; \mathrm{S}, 7.43$. found: $\mathrm{C}$, 50.09; H, 3.56; N, 12.97; S, 7.45. HRMS: $431.2205[\mathrm{M}+\mathrm{H}]^{+}$.

4.1.2.9. (E)-2-\{2-[1-(3-bromophenyl)propylidene]hydrazinyl\}-4-(3,4dichlorophenyl)thiazole (1i). $60 \%$ yield; $\mathrm{mp}\left({ }^{\circ} \mathrm{C}\right)$ : $228-231$; $\mathrm{IR}(\mathrm{KBr}$, $\left.\mathrm{cm}^{-1}\right): 3642.77$ and $2971.43(\mathrm{CH} \mathrm{Ar}), 1475.20(\mathrm{C}=\mathrm{N}) ;{ }^{1} \mathrm{H}$ NMR $\left(\right.$ DMSO- $\left._{6}, 300 \mathrm{MHz}\right) \delta \mathrm{ppm}: 1.04\left(\mathrm{t}, J=7.5 \mathrm{~Hz}, 3 \mathrm{H}, \mathrm{CH}_{3}\right), 2.84$ (q, $\left.J=7.5 \mathrm{~Hz}, 2 \mathrm{H}, \mathrm{CH}_{2}\right), 5.29(\mathrm{~s}, 1 \mathrm{H}, \mathrm{NH}), 7.35-8.10(\mathrm{~m}, 8 \mathrm{H}, \mathrm{Ar}) ;{ }^{13} \mathrm{C} \mathrm{NMR}$ $\left(\right.$ DMSO- $\left.d_{6}, 75.5 \mathrm{MHz}\right) \delta \mathrm{ppm}: 10.6\left(\mathrm{CH}_{3}\right), 19.6\left(\mathrm{CH}_{2}\right), 106.6(\mathrm{CH}$, thiazole), 122.2 (Ar), 124.8 ( $\mathrm{Ar}), 125.6(\mathrm{Ar}), 127.2$ ( $\mathrm{Ar}), 128.2$ ( $\mathrm{Ar}$ ), 129.7 ( $\mathrm{Ar}), 130.8$ ( $\mathrm{Ar}), 131.5(\mathrm{Ar}), 135.2(\mathrm{Ar}), 139.0(\mathrm{Ar}), 147.9(\mathrm{Ar})$, $149.3(\mathrm{Ar}), 150.4(\mathrm{C}-\mathrm{N}$, thiazole $), 149.3(\mathrm{C}=\mathrm{N}), 169.8(\mathrm{~S}-\mathrm{C}=\mathrm{N}$, thiazole). Anal. Calcd for $\mathrm{C}_{18} \mathrm{H}_{14} \mathrm{BrCl}_{2} \mathrm{~N}_{3} \mathrm{~S}$ : C, 47.49; H, 3.10; N, 9.23; S, 7.04. found: C, 47.47; H, 3.13; N, 9.26; S, 7.06. HRMS: 451.8046 $[\mathrm{M}-\mathrm{H}]^{-}$.

4.1.2.10. (E)-2-\{2-[1-(3-bromophenyl)propylidene]hydrazinyl $\}$-4(2,4-dichlorophenyl)thiazole (1j). 66\% yield; $\mathrm{mp}\left({ }^{\circ} \mathrm{C}\right)$ : $174-179$; IR $\left(\mathrm{KBr}, \mathrm{cm}^{-1}\right): 1518.07(\mathrm{C}=\mathrm{N}) ;{ }^{1} \mathrm{H}$ NMR $\left(\mathrm{DMSO}-\mathrm{d}_{6}, 400 \mathrm{MHz}\right) \delta \mathrm{ppm}$ : $1.06\left(\mathrm{t}, J=7.6 \mathrm{~Hz}, 3 \mathrm{H}, \mathrm{CH}_{3}\right), 2.84\left(\mathrm{q}, J=7.6 \mathrm{~Hz}, 2 \mathrm{H}, \mathrm{CH}_{2}\right), 4.04(\mathrm{~s}, 1 \mathrm{H}$, $\mathrm{NH}), 7.38-7.94(\mathrm{~m}, 8 \mathrm{H}, \mathrm{Ar}) ;{ }^{13} \mathrm{C}$ NMR (DMSO- $\left.d_{6}, 75.5 \mathrm{MHz}\right) \delta \mathrm{ppm}$ : $10.6\left(\mathrm{CH}_{3}\right), 19.6\left(\mathrm{CH}_{2}\right), 109.8(\mathrm{CH}$, thiazole $), 122.1(\mathrm{Ar}), 124.8(\mathrm{Ar})$, 125.6 (Ar), 127.5 (Ar), 128.2 (Ar), 129.7 (Ar), 130.7 (Ar), 131.3 (Ar), 131.6 (Ar), 132.3 (Ar), 132.6 (Ar), 135.2 (Ar), 139.0 (C-N, thiazole), 
149.3 $(\mathrm{C}=\mathrm{N}), \quad 168.8 \quad(\mathrm{~S}-\mathrm{C}=\mathrm{N}$, thiazole). Anal. Calcd for $\mathrm{C}_{18} \mathrm{H}_{14} \mathrm{BrCl}_{2} \mathrm{~N}_{3} \mathrm{~S}$ : C, 47.49; H, 3.10; N, 9.23; S, 7.04. found: C, 47.45; $\mathrm{H}$, 3.13; N, 9.28; S, 7.05. HRMS: $451.9214[\mathrm{M}-\mathrm{H}]^{-}$.

4.1.2.11. (E)-2-\{2-[1-(3-bromophenyl)propylidene]hydrazinyl $\}-4-$ (naphthalen-2-yl)thiazole (1k). 57\% yield; mp $\left({ }^{\circ} \mathrm{C}\right)$ : $198-201$; IR $\left(\mathrm{KBr}, \mathrm{cm}^{-1}\right): 1614.36(\mathrm{C}=\mathrm{N}) ;{ }^{1} \mathrm{H}$ NMR (DMSO- $\left.d_{6}, 300 \mathrm{MHz}\right) \delta \mathrm{ppm}$ : $1.36\left(\mathrm{t}, J=7.6 \mathrm{~Hz}, 3 \mathrm{H}, \mathrm{CH}_{3}\right), 2.97\left(\mathrm{q}, J=7.6 \mathrm{~Hz}, 2 \mathrm{H}, \mathrm{CH}_{2}\right), 6.92(\mathrm{~s}, 1 \mathrm{H}$, thiazole), 7.31 (t, $J=7.5 \mathrm{~Hz}, 1 \mathrm{H}, \mathrm{Ar}), 7.52-7.59(\mathrm{~m}, 3 \mathrm{H}, \mathrm{Ar}), 7.68-7.73$ $(\mathrm{m}, 2 \mathrm{H}, \mathrm{Ar}), 7.82(\mathrm{t}, J=4,6 \mathrm{~Hz}, 1 \mathrm{H}, \mathrm{Ar}), 7.90-7.98(\mathrm{~m}, 3 \mathrm{H}, \mathrm{Ar}), 8.26(\mathrm{~s}$, $1 \mathrm{H}, \mathrm{Ar}), 13.02(\mathrm{~s}, 1 \mathrm{H}, \mathrm{NH}) ;{ }^{13} \mathrm{C}$ NMR (DMSO-d 6 , $\left.75.5 \mathrm{MHz}\right) \delta_{\mathrm{ppm}}: 11.1$ $\left(\mathrm{CH}_{3}\right), 22.4\left(\mathrm{CH}_{2}\right), 101.6(\mathrm{CH}$, thiazole), $120.0(\mathrm{Ar}), 122.2(\mathrm{Ar}), 123.0$ (Ar), 124.2 (Ar), 125.4 (Ar), 125.6 (Ar), $127.3(\mathrm{Ar}), 127.7$ (Ar), 128.9 (Ar), 129.6 (Ar), 129.7 (Ar), 130.3 (Ar), 133.1 (Ar), 133.5 (Ar), 133.8 (Ar), $136.9(\mathrm{Ar}), 140.9(\mathrm{C}-\mathrm{N}$, thiazole $), 159.6(\mathrm{C}=\mathrm{N}), 170.1(\mathrm{~S}-\mathrm{C}=\mathrm{N}$, thiazole). Anal. Calcd for $\mathrm{C}_{22} \mathrm{H}_{18} \mathrm{BrN}_{3} \mathrm{~S}: \mathrm{C}, 60.55 ; \mathrm{H}, 4.16 ; \mathrm{N}, 9.63 ; \mathrm{S}$, 7.35. found: C, 60.57 ; H, 4.14; N, 9.59; S, 7.40. HRMS: 436.1018 $[\mathrm{M}+\mathrm{H}]^{+}$.

4.1.2.12. (E)-2-\{2-[1-(3-bromophenyl)propylidene]hydrazinyl\}-5methyl-4-phenylthiazole (1l). $62 \%$ yield; $\mathrm{mp}\left({ }^{\circ} \mathrm{C}\right): 202-206 ; \mathrm{IR}(\mathrm{KBr}$, $\left.\mathrm{cm}^{-1}\right): 1614.94(\mathrm{C}=\mathrm{N}) ;{ }^{1} \mathrm{H}$ NMR (DMSO- $\left.d_{6}, 300 \mathrm{MHz}\right) \delta_{\mathrm{ppm}}: 1.32(\mathrm{t}$, $\left.J=7.6 \mathrm{~Hz}, 3 \mathrm{H}, \mathrm{CH}_{3}\right), 2.46\left(\mathrm{~s}, 3 \mathrm{H}, \mathrm{CH}_{3}\right), 2.96\left(\mathrm{q}, J=7.6 \mathrm{~Hz}, 2 \mathrm{H}, \mathrm{CH}_{2}\right)$, $7.30(\mathrm{t}, 1 \mathrm{H}, \mathrm{Ar}), 7.45-7.57(\mathrm{~m}, 6 \mathrm{H}, \mathrm{Ar}), 7.68(\mathrm{~d}, 1 \mathrm{H}, \mathrm{Ar}), 7.93(\mathrm{~s}, 1 \mathrm{H}, \mathrm{Ar})$, 12.9 (s, $1 \mathrm{H}, \mathrm{NH}) ;{ }^{13} \mathrm{C}$ NMR (DMSO- $\left.d_{6}, 75.5 \mathrm{MHz}\right) \delta \mathrm{ppm}: 11.1\left(\mathrm{CH}_{3}\right)$, $12.3\left(\mathrm{CH}_{3}\right), 22.3\left(\mathrm{CH}_{2}\right), 115.9$ (C, thiazole), $120.0(\mathrm{Ar}), 122.9(\mathrm{Ar})$, $125.3(\mathrm{Ar}), 127.8(\mathrm{Ar}), 129.5(\mathrm{Ar}), 129.6(\mathrm{Ar}), 129.9(\mathrm{Ar}), 130.2(\mathrm{Ar})$, 133.3 (Ar), $135.2(\mathrm{Ar}), 137.1(\mathrm{C}-\mathrm{N}$, thiazole), $159.1(\mathrm{C}=\mathrm{N}), 167.6$ ( $\mathrm{S}-\mathrm{C}=\mathrm{N}$, thiazole). Anal. Calcd for $\mathrm{C}_{19} \mathrm{H}_{18} \mathrm{BrN}_{3} \mathrm{~S}$ : C, 57.00; $\mathrm{H}, 4.53 ; \mathrm{N}$, 10.50; S, 8.01. found: C, 57.07; H, 4.49; N, 10.45; S, 8.09. HRMS: $400.0076[\mathrm{M}+\mathrm{H}]^{+}$.

4.1.2.13. (E)-4-(4-bromophenyl)-2-\{2-[1-(3-bromophenyl)propylidene Jhydrazinyl\}-5-methylthiazole $(1 \mathrm{~m}) .61 \%$ yield; $\mathrm{mp}\left({ }^{\circ} \mathrm{C}\right)$ : 192-197; IR $\left(\mathrm{KBr}, \mathrm{cm}^{-1}\right)$ : $1614.94(\mathrm{C}=\mathrm{N}) ;{ }^{1} \mathrm{H}$ NMR (DMSO-d $d_{6}$, $300 \mathrm{MHz}) \delta_{\mathrm{ppm}}: 1.05\left(\mathrm{t}, J=7.2 \mathrm{~Hz}, 3 \mathrm{H}, \mathrm{CH}_{3}\right), 2.40\left(\mathrm{~s}, 3 \mathrm{H}, \mathrm{CH}_{3}\right), 2.83$ (q, $\left.J=7.2 \mathrm{~Hz}, 2 \mathrm{H}, \mathrm{CH}_{2}\right), 4.64(\mathrm{~s}, 1 \mathrm{H}, \mathrm{NH}), 7.38(\mathrm{t}, J=7.8 \mathrm{~Hz}, 1 \mathrm{H}, \mathrm{Ar})$, $7.58(\mathrm{~m}, 5 \mathrm{H}, \mathrm{Ar}), 7.76(\mathrm{~d}, J=7.2 \mathrm{~Hz}, 1 \mathrm{H}, \mathrm{Ar}), 7.94(\mathrm{~s}, 1 \mathrm{H}, \mathrm{Ar}) ;{ }^{13} \mathrm{C} \mathrm{NMR}$ (DMSO- $\left.d_{6}, 75.5 \mathrm{MHz}\right) \delta$ ppm: $10.6\left(\mathrm{CH}_{3}\right), 12.1\left(\mathrm{CH}_{3}\right), 19.6\left(\mathrm{CH}_{2}\right), 118.2$ (C, thiazole), $120.6(\mathrm{Ar}), 122.1(\mathrm{Ar}), 124.8(\mathrm{Ar}), 125.6(\mathrm{Ar}), 127.8(\mathrm{Ar})$, 128.2 (Ar), 129.2 (Ar), 130.1 (Ar), 130.7 (Ar), 131.3 (Ar), 138.9 (C-N, thiazole), $149.2(\mathrm{C}=\mathrm{N}), 165.8(\mathrm{~S}-\mathrm{C}=\mathrm{N}$, thiazole). Anal. Calcd for $\mathrm{C}_{19} \mathrm{H}_{17} \mathrm{Br}_{2} \mathrm{~N}_{3} \mathrm{~S}$ : C, 47.62; H, 3.58; N, 8.77; S, 6.69. found: $\mathrm{C}, 47.64 ; \mathrm{H}$, 3.59; N, 8.73; S, 6.71. HRMS: $475.5986[\mathrm{M}-\mathrm{H}]^{-}$.

4.1.2.14. (E)-2-\{(Z)-[1-(3-bromophenyl)propylidene]hydrazono\}-4(4-methoxyphenyl)-3-methyl-2,3-dihydrothiazole (2c). 63\% yield; $\mathrm{mp}\left({ }^{\circ} \mathrm{C}\right)$ : $185-190 ; \mathrm{IR}\left(\mathrm{KBr}, \mathrm{cm}^{-1}\right): 1583.39(\mathrm{C}=\mathrm{N}) ;{ }^{1} \mathrm{H}$ NMR (DMSO$\left.d_{6}, 300 \mathrm{MHz}\right), \delta \mathrm{ppm}: 1.80\left(\mathrm{t}, J=7.6 \mathrm{~Hz}, 3 \mathrm{H}, \mathrm{CH}_{3}\right), 3.97(\mathrm{q}, J=7.4 \mathrm{~Hz}$, $\left.2 \mathrm{H}, \mathrm{CH}_{2}\right), 4.42\left(\mathrm{~s}, 3 \mathrm{H}, \mathrm{CH}_{3}\right), 4.68\left(\mathrm{~s}, 3 \mathrm{H}, \mathrm{CH}_{3}\right), 7.56(\mathrm{~d}, \mathrm{~J}=8.7 \mathrm{~Hz}, 2 \mathrm{H}$, $\mathrm{Ar}), 7.81-7.89(\mathrm{~m}, 3 \mathrm{H}, \mathrm{Ar}), 8.12(\mathrm{~d}, J=7.5 \mathrm{~Hz}, 1 \mathrm{H}, \mathrm{Ar}), 8.22(\mathrm{~d}$, $J=8.4 \mathrm{~Hz}, 1 \mathrm{H}, \mathrm{Ar}), 8.46(\mathrm{~s}, 1 \mathrm{H}, \mathrm{Ar}), 13.61(\mathrm{~s}, 1 \mathrm{H}, \mathrm{NH}) ;{ }^{13} \mathrm{C} \mathrm{NMR}$ (DMSO- $\left.d_{6}, 75.5 \mathrm{MHz}\right), \delta$ ppm: $11.4\left(\mathrm{CH}_{3}\right), 24.1\left(\mathrm{CH}_{2}\right), 39.9\left(\mathrm{CH}_{3}\right), 55.5$ $\left(\mathrm{CH}_{3}\right), 106.9$ (CH, thiazole), 114.8 (Ar), $119.7(\mathrm{Ar}), 122.8(\mathrm{Ar}), 125.8$ (Ar), 130.2 (Ar), 130.8 (Ar), 133.3 (Ar), 136.5 (Ar), 137.6 (Ar), 144.5 (Ar), $161.5(\mathrm{C}-\mathrm{N}$, thiazole), $163.8(\mathrm{C}=\mathrm{N}), 171.7(\mathrm{~S}-\mathrm{C}-\mathrm{N}$, thiazole). Anal. Calcd for $\mathrm{C}_{20} \mathrm{H}_{20} \mathrm{BrN}_{3} \mathrm{OS}$ : C, 55.82; H, 4.68; N, 9.76; S, 7.45. found: C, 55.86; H, 4.63; N, 9.76; S, 7.42. HRMS: $430.0137[\mathrm{M}+\mathrm{H}]^{+}$.

4.1.2.15. (E)-2-\{(Z)-[1-(3-bromophenyl)propylidene]hydrazono\}-3,4diphenyl-2,3-dihydrothiazole (3c). 69\% yield; $\mathrm{mp}\left({ }^{\circ} \mathrm{C}\right)$ : 246-250; IR $\left(\mathrm{KBr}, \mathrm{cm}^{-1}\right): 1585.32(\mathrm{C}=\mathrm{N}) ;{ }^{1} \mathrm{H}$ NMR (DMSO-d $\left.d_{6}, 400 \mathrm{MHz}\right), \delta \mathrm{ppm}$ : $1.80\left(\mathrm{t}, J=6.0 \mathrm{~Hz}, 3 \mathrm{H}, \mathrm{CH}_{3}\right), 2.58\left(\mathrm{q}, J=6.0 \mathrm{~Hz}, 2 \mathrm{H}, \mathrm{CH}_{2}\right), 3.86(\mathrm{~s}, 3 \mathrm{H}$, $\left.\mathrm{CH}_{3}\right), 6.63(\mathrm{~s}, 1 \mathrm{H}$, Thiazole), $7.01(\mathrm{~d}, J=6.8 \mathrm{~Hz}, 2 \mathrm{H}, \mathrm{Ar}), 7.18-7.32(\mathrm{~m}$, $5 \mathrm{H}, \mathrm{Ar}$ ), 7.58-7.70 (m, 5H, Ar), $7.95(\mathrm{~s}, 1 \mathrm{H}, \mathrm{Ar}) ;{ }^{13} \mathrm{C}$ NMR (DMSO-d $d_{6}$,
$75.5 \mathrm{MHz}), \delta$ ppm: $55.5\left(\mathrm{CH}_{3}\right), 70.7\left(\mathrm{CH}_{2}\right), 99.0\left(\mathrm{CH}_{3}\right), 115.1(\mathrm{CH}$, thiazole), $123.0(\mathrm{Ar}), 125.3(\mathrm{Ar}), 127.3(\mathrm{Ar}), 128.2(\mathrm{Ar}), 128.9(\mathrm{Ar})$, 129.0 (Ar), 129.5 (Ar), 129.6 (Ar), 1310.2 (Ar), 130.2 (Ar), 130.6 (Ar), 133.5 (Ar), $138.1(\mathrm{Ar}), 144.0(\mathrm{Ar}), 161.0(\mathrm{C}-\mathrm{N}$, thiazole $), 164.1(\mathrm{C}=\mathrm{N})$, 172.0 (S-C-N, thiazole). Anal. Calcd for $\mathrm{C}_{24} \mathrm{H}_{20} \mathrm{BrN}_{3} \mathrm{~S}$ : C, 62.34; $\mathrm{H}$, 4.36; N, 9.09; S, 6.93. found: C, 62.36; H, 4.33; N, 9.06; S, 6.89. HRMS: $492.1973[\mathrm{M}+\mathrm{H}]^{+}$.

\subsection{Biological assays}

\subsubsection{Toxicity to splenocytes}

Splenocytes from BALB/c mice were divided into plate with 96 wells at a density of $5 \times 10^{6}$ cells per wells in RPMI-1640 medium containing 10\% inactivated Fetal Bovine Serum (FBS). Each chemical inhibitor was dissolved in DMSO at the concentration of $10 \mathrm{mg} / \mathrm{mL}$ and then the sample was serially diluted in RPMI-1640 medium supplemented with $10 \%$ FBS at the concentrations of 1.0, 5.0, 10, 25, 50 and $100 \mu \mathrm{g} / \mathrm{mL}$, in triplicate. As a positive control, we used saponin in concentration of $0.1 \mu \mathrm{g} / \mathrm{mL}$, while as the negative control wells received only an RPMI-1640 medium supplemented with $10 \%$ FBS and DMSO. The plate was added $1.0 \mu \mathrm{Ci}$ of ${ }^{3} \mathrm{H}$ - hymidine to each well and the plate was incubated for $24 \mathrm{~h}$ at $37{ }^{\circ} \mathrm{C}$ and $5 \% \mathrm{CO}_{2}$. The plate was then read in the counter beta irradiation (Multilabel Reader, Finland) and tritiated thymidine percent incorporation was determined. For cells that were not treated with drugs (negative control) was calculated as $100 \%$ of tritiated thymidine incorporation (100\% viable cells). For cells treated with saponin, cell viability was $5 \%$. When the percentage of incorporation was higher than $90 \%$, the concentration of the drug was regarded as nontoxic to splenocytes.

\subsubsection{Toxicity to trypomastigotes}

Strain Y trypomastigotes were collected from Vero cells supernatant and distributed in a plate with 96 wells for a final density of $4 \times 10^{5}$ cells per well. Each chemical inhibitor was added to the wells in triplicate. Benznidazole were used as positive controls in this assay. The plate was then cultivated for $24 \mathrm{~h}$ at $37^{\circ} \mathrm{C}$ containing $5 \% \mathrm{CO}_{2}$. After this time, aliquots from each well were collected and the number of viable parasites (ie, with apparent motility) was counted in a Neubauer chamber. To the wells that did not receive the chemical inhibitors, it was assumed as $100 \%$ the number of viable parasites. The dose-response curves were determined and the $\mathrm{IC}_{50}$ values $(\mu \mathrm{M})$ were calculated using at least seven concentrations (data-points) using nonlinear regression (Prism, version 4.0).

\subsubsection{Ultrastructural studies}

The parasites were cultured for $24 \mathrm{~h}$ in medium RPMI 1640 medium (SigmaAldrich, St. Louis, MO, USA) buffered to $\mathrm{pH} 7.5$, supplemented with HEPES $(20 \mathrm{mM}), 10 \%$ fetal bovine serum, penicillin $(100 \mathrm{U} / \mathrm{mL})$, and streptomycin $(100 \mu \mathrm{g} / \mathrm{mL})$ containing the compound $1 \mathrm{c}$ in $\mathrm{IC}_{50}$ concentration and twice the value of $\mathrm{IC}_{50}$. The parasites were collected, washed in PBS and fixed with $2.5 \%$ glutaraldehyde, $4 \%$ formaldehyde, and $0.1 \mathrm{M}$ cacodylate buffer at $\mathrm{pH}$ 6.8. They were then postfixed in $2 \%$ osmium tetroxide $\left(\mathrm{OsO}_{4}\right)$ in a $0.1 \mathrm{M}$ cacodylate buffer at $\mathrm{pH} 6.8$ and processed for routine transmission electron microscopy (TEM) and scanning electron microscopy (SEM). For SEM analysis, the parasites were dehydration in a graded ethanol, dried by the critical point method with $\mathrm{CO}_{2}$. The samples were mounted on aluminum stubs, coated with gold and examined under a JEOL-5600LV microscope. For TEM analysis, the parasites were dehydration in a graded series of acetone and finally embedded in epon. Sections were stained with uranyl acetate and lead citrate and observed with Tecnai spirit G2 Biotwin microscope. 


\subsubsection{Cruzain analysis}

Recombinant cruzain truncated at the C-terminal was kindly provided by Allison Doak and Brian Shoichet (UCSF, USA). Cruzain activity was monitored as previously reported, based on the fluorescence resulting from the cleavage of the substrate Z-Phe-Argaminomethylcoumarin (Z-FR-AMC), with 340/440 nm excitation/ emission filters. The assays were carried in a microplate reader Synergy 2 (Biotek ${ }^{\circledR}$ ) from the Center of Flow Cytometry and Fluorimetry at the Biochemistry and Immunology Department (UFMG). Fluorescence was measured at $25{ }^{\circ} \mathrm{C}$, for five minutes at $12 \mathrm{~s}$ intervals, using BioTek's Gen5 ${ }^{\mathrm{TM}}$ Reader Control and Data Analysis Software. Reaction rates were calculated from initial velocity rates compared to a DMSO control. Compounds were tested in sodium acetate buffer $0.1 \mathrm{M}$, pH 5.5, containing $0.01 \%$ Triton X-100, $1 \mathrm{mM} \beta$ mercaptoethanol, $1 \mathrm{nM}$ cruzain and $2,5 \mu \mathrm{M}$ substrate. There was no pre-incubation with the enzyme. All assays were performed in at least twice in independent experiments, each performed in triplicate. When the inhibition was higher than $80 \%$ at highest soluble concentration for the compounds evaluated (300, 200 and $100 \mu \mathrm{M})$, $\mathrm{IC}_{50}$ curves were determined based on seven different compound concentrations and calculated using GraphPad Prism 6 (GraphPad, San Diego, USA), employing the nonlinear regression "log (inhibitor) vs response with variable slope - four parameters" analysis.

\subsection{Docking studies}

The compounds 1a-b, 1d-e and $\mathbf{1 h}-\mathbf{m}$ were selected for in silico studies, because their inhibitory potency $\left(\mathrm{IC}_{50}\right)$ was measured against the cysteine protease of Trypanosoma cruzi (cruzain), as one can see in Table 3. The structures and conformational analysis were obtained through the application of the RM1 semi-empirical approach [41], which is available as part of the SPARTAN 08' program [42], using internal default settings for convergence criteria. The analysis and docking calculation were carried using the $T$. cruzi cruzain target [15], available at the RCSB Protein Data Bank (PDB ID: 3IUT), which is composed of a co-crystallized complex with an inhibitor (referred as KB2). The space for searching of docking solutions was defined to lie within a region of $27.0 \AA$ in direction $X$, $25.5 \AA$ in direction $Y$, and $31.5 \AA$ in direction $Z$, centered on the coordinates based on the reference of the co-crystallized ligand KB2 $(\mathrm{X}=2.772 ; \mathrm{Y}=12.987 ; \mathrm{Z}=4.357$; all in $\AA$ ). The docking calculations were carried out using the AutoDockTools and AutoDock (v.4.2) programs [43], using the default parameters for all the variables, except for the number of docking runs (50), the maximum number of energy evaluations on Genetic Algorithm-GA $(25,000,000)$, and the maximum number of generations in GA $(10,000)$. Preliminary calculations indicate that these three specific parameter modifications provide significant improvement in the results obtained using the docking procedure, thereby producing more significant solutions. The ligands were then docked using the Genetic Algorithm followed by a Local Search procedure (GA_LS), also known as a Lamarckian Genetic Algorithm (LGA), and the 50 lowest energy structures were stored for further analysis. The residues GLN19, CYS25, SER61, LEU67, MET68, ASN70, ASP161, HIS162 and TRP184 were treated as flexible during the calculations, in order to take into account some induced fit effects. The Binana program [44] was used to analyze the molecular interactions present in the best docking solutions, using default setting, except for hydrogen bond distance, which was changed to a maximum of 3.5 A. Figures were generated with Pymol software [45].

\section{Acknowledgement}

This work received funding by CNPq (grant number 471461/ 2011-3 to A.C.L.L.), CAPES (grant number 23038.003155/2011-37 to
V.R.A.P.) PRONEX-FAPESB (grant number 8804-2014 to D.R.M.M.) and PRONEM/FACEPE/CNPq (grant number APQ-054902.11/14 to V.R.A.P.). P.A.T.M.G. is supported by FACEPE (grant number IBPG0117-4.03/12). A.C.L.L. and M.Z.H. is receiving a CNPq senior fellowship.

\section{Appendix A. Supplementary data}

Supplementary data related to this article can be found at http:// dx.doi.org/10.1016/j.ejmech.2016.05.050.

\section{References}

[1] WHO, Chagas Disease (American Trypanosomiasis), 2015. http://www.who, int/mediacentre/factsheets/fs340/en/index.html.

[2] J.R. Coura, J.C.P. Dias, Epidemiology, control and surveillance of Chagas disease: 100 years after its discovery, Mem. Inst. Oswaldo Cruz. 104 (Suppl) (2009) 31-40, http://dx.doi.org/10.1590/S0074-02762009000900006.

[3] R.L. Tarleton, J.W. Curran, Is chagas disease really the "new HIV/AIDS of the Americas"? PLoS Negl. Trop. Dis. 6 (2012) e1861, http://dx.doi.org/10.1371/ journal.pntd.0001861.

[4] F.S. Buckner, J.A. Urbina, Recent developments in sterol 14-demethylase inhibitors for Chagas disease, Int. J. Parasitol. Drugs Drug Resist. 2 (2012) 236-242, http://dx.doi.org/10.1016/j.ijpddr.2011.12.002.

[5] F.S. Machado, L.A. Jelicks, L.V. Kirchhoff, J. Shirani, F. Nagajyothi, S. Mukherjee, et al., Chagas heart disease, Cardiol. Rev. 20 (2012) 1, http://dx.doi.org/ 10.1097/CRD.0b013e31823efde2.

[6] M.-J. Pinazo, J. Muñoz, E. Posada, P. López-Chejade, M. Gállego, E. Ayala, et al., Tolerance of benznidazole in treatment of Chagas' disease in adults, Antimicrob. Agents Chemother. 54 (2010) 4896-4899, http://dx.doi.org/10.1128/ AAC.00537-10.

[7] J.C. Mottram, D.R. Brooks, G.H. Coombs, Roles of cysteine proteinases of trypanosomes and Leishmania in host-parasite interactions, Curr. Opin. Microbiol. 1 (1998) 455-460.

[8] E.E. Caroselli, D.M. Assis, C.L. Barbiéri, W.A.S. Júdice, M.A. Juliano, M.L. Gazarini, et al., Leishmania (L.) amazonensis peptidase activities inside the living cells and in their lysates, Mol. Biochem. Parasitol. 184 (2012) 82-89, http:// dx.doi.org/10.1016/j.molbiopara.2012.04.012.

[9] X. Du, E. Hansell, J.C. Engel, C.R. Caffrey, F.E. Cohen, J.H. McKerrow, Aryl ureas represent a new class of anti-trypanosomal agents, Chem. Biol. 7 (2000) 733-742, http://dx.doi.org/10.1016/S1074-5521(00)00018-1.

[10] H.J. Wiggers, J.R. Rocha, W.B. Fernandes, R. Sesti-Costa, Z.A. Carneiro, J. Cheleski, et al., Non-peptidic cruzain inhibitors with trypanocidal activity discovered by virtual screening and in vitro assay, PLoS Negl. Trop. Dis. 7 (2013) e2370, http://dx.doi.org/10.1371/journal.pntd.0002370.

[11] J.M. dos Santos Filho, A.C.L. Leite, B.G. de Oliveira, D.R.M. Moreira, M.S. Lima, M.B.P. Soares, et al., Design, synthesis and cruzain docking of 3-(4substituted-aryl)-1,2,4-oxadiazole-N-acylhydrazones as anti-Trypanosoma cruzi agents, Bioorg. Med. Chem. 17 (2009) 6682-6691, http://dx.doi.org/ 10.1016/j.bmc.2009.07.068.

[12] N.C. Romeiro, G. Aguirre, P. Hernández, M. González, H. Cerecetto, I. Aldana, et al., Synthesis, trypanocidal activity and docking studies of novel quinoxaline$\mathrm{N}$-acylhydrazones, designed as cruzain inhibitors candidates, Bioorg. Med. Chem. 17 (2009) 641-652, http://dx.doi.org/10.1016/j.bmc.2008.11.065.

[13] J.M. dos Santos Filho, D.R.M. Moreira, C.A. De Simone, R.S. Ferreira, J.H. McKerrow, C.S. Meira, et al., Optimization of anti-Trypanosoma cruzi oxadiazoles leads to identification of compounds with efficacy in infected mice, Bioorg. Med. Chem. 20 (2012) 6423-6433, http://dx.doi.org/10.1016/ j.bmc.2012.08.047.

[14] T. Franklim, L. Freire-de-Lima, J. de Nazareth Sá Diniz, J. Previato, R. Castro, L. Mendonça-Previato, et al., Design, synthesis and trypanocidal evaluation of novel 1,2,4-Triazoles-3-thiones derived from natural piperine, Molecules 18 (2013) 6366-6382, http://dx.doi.org/10.3390/molecules18066366.

[15] K. Brak, I.D. Kerr, K.T. Barrett, N. Fuchi, M. Debnath, K. Ang, et al., Nonpeptidic tetrafluorophenoxymethyl ketone cruzain inhibitors as promising new leads for Chagas disease chemotherapy, J. Med. Chem. 53 (2010) 1763-1773, http:// dx.doi.org/10.1021/jm901633v.

[16] K. Brak, P.S. Doyle, J.H. McKerrow, J.A. Ellman, Identification of a new class of nonpeptidic inhibitors of cruzain, J. Am. Chem. Soc. 130 (2008) 6404-6410, http://dx.doi.org/10.1021/ja710254m.

[17] X. Du, C. Guo, E. Hansell, P.S. Doyle, C.R. Caffrey, T.P. Holler, et al., Synthesis and structure-activity relationship study of potent trypanocidal thio semicarbazone inhibitors of the trypanosomal cysteine protease cruzain, J. Med. Chem. 45 (2002) 2695-2707, http://dx.doi.org/10.1021/jm010459j.

[18] D.C. Greenbaum, Z. Mackey, E. Hansell, P. Doyle, J. Gut, C.R. Caffrey, et al., Synthesis and structure-activity relationships of parasiticidal thiosemicarbazone cysteine protease inhibitors against Plasmodium falciparum, Trypanosoma brucei, and Trypanosoma cruzi, J. Med. Chem. 47 (2004) 3212-3219, http://dx.doi.org/10.1021/jm030549j.

[19] R. Siles, S.-E. Chen, M. Zhou, K.G. Pinney, M.L. Trawick, Design, synthesis, and biochemical evaluation of novel cruzain inhibitors with potential application 
in the treatment of Chagas' disease, Bioorg. Med. Chem. Lett. 16 (2006) 4405-4409, http://dx.doi.org/10.1016/j.bmcl.2006.05.041.

[20] J.W.P. Espíndola, M.V. de O. Cardoso, G.B. de O. Filho, D.A. Oliveira e Silva, D.R.M. Moreira, T.M. Bastos, et al., Synthesis and structure-activity relationship study of a new series of antiparasitic aryloxyl thiosemicarbazones inhibiting Trypanosoma cruzi cruzain, Eur. J. Med. Chem. 101 (2015) 818-835, http://dx.doi.org/10.1016/j.ejmech.2015.06.048

[21] N. Fujii, J.P. Mallari, E.J. Hansell, Z. Mackey, P. Doyle, Y.M. Zhou, et al., Discovery of potent thiosemicarbazone inhibitors of rhodesain and cruzain, Bioorg. Med. Chem. Lett. 15 (2005) 121-123, http://dx.doi.org/10.1016/ j.bmcl.2004.10.023.

[22] I. Chiyanzu, E. Hansell, J. Gut, P.J. Rosenthal, J.H. McKerrow, K. Chibale, Synthesis and evaluation of isatins and thiosemicarbazone derivatives against cruzain, falcipain-2 and rhodesain, Bioorg. Med. Chem. Lett. 13 (2003) 3527-3530, http://dx.doi.org/10.1016/S0960-894X(03)00756-X.

[23] N.C. Fonseca, L.F. da Cruz, F. da Silva Villela, G.A. do Nascimento Pereira, J.L. de Siqueira-Neto, D. Kellar, et al., Synthesis of a sugar-based thiosemicarbazone series and structure-activity relationship versus the parasite cysteine proteases rhodesain, cruzain, and schistosoma mansoni cathepsin B1, Antimicrob. Agents Chemother. 59 (2015) 2666-2677, http://dx.doi.org/10.1128/ AAC.04601-14.

[24] D.R.M. Moreira, A.C. Lima Leite, M.V.O. Cardoso, R.M. Srivastava, M.Z. Hernandes, M.M. Rabello, et al., Structural design, synthesis and structure-activity relationships of thiazolidinones with enhanced antitrypanosoma cruzi activity, ChemMedChem 9 (2014) 177-188, http:// dx.doi.org/10.1002/cmdc.201300354.

[25] D.R. Magalhaes Moreira, A. Lima Leite, R.R. Santos, M. Soares, Approaches for the development of new anti-trypanosoma cruzi agents, Curr. Drug Targets 10 (2009) 212-231, http://dx.doi.org/10.2174/138945009787581140.

[26] A. Ayati, S. Emami, A. Asadipour, A. Shafiee, A. Foroumadi, Recent applications of 1,3-thiazole core structure in the identification of new lead compounds and drug discovery, Eur. J. Med. Chem. (2015) 1-20, http://dx.doi.org/10.1016/ j.ejmech.2015.04.015.

[27] D.R.M. Moreira, S.P.M. Costa, M.Z. Hernandes, M.M. Rabello, G.B. de Oliveira Filho, C.M.L. de Melo, et al., Structural investigation of anti-Trypanosoma cruzi 2-iminothiazolidin-4-ones allows the identification of agents with efficacy in infected mice, J. Med. Chem. 55 (2012) 10918-10936, http://dx.doi.org/ $10.1021 / \mathrm{jm} 301518 \mathrm{v}$

[28] M.Z. Hernandes, M.M. Rabello, A.C.L. Leite, M.V.O. Cardoso, D.R.M. Moreira, D.J. Brondani, et al., Studies toward the structural optimization of novel thiazolylhydrazone-based potent antitrypanosomal agents, Bioorg. Med. Chem. 18 (2010) 7826-7835, http://dx.doi.org/10.1016/j.bmc.2010.09.056.

[29] A.C.L. Leite, R.S. de Lima, D.R.D.M. Moreira, M.V.D.O. Cardoso, A.C. Gouveia de Brito, L.M. Farias Dos Santos, et al., Synthesis, docking, and in vitro activity of thiosemicarbazones, aminoacyl-thiosemicarbazides and acyl-thiazolidones against Trypanosoma cruzi, Bioorg. Med. Chem. 14 (2006) 3749-3757, http://dx.doi.org/10.1016/j.bmc.2006.01.034.

[30] A.C.L. Leite, D.R. de M. Moreira, M.V. de O. Cardoso, M.Z. Hernandes, V.R. Alves Pereira, R.O. Silva, et al., Synthesis, Cruzain docking, and in vitro studies of aryl-4-oxothiazolylhydrazones against Trypanosoma cruzi, ChemMedChem 2 (2007) 1339-1345, http://dx.doi.org/10.1002/cmdc.200700022.

[31] M.V. de O. Cardoso, L.R.P. de Siqueira, E.B. da Silva, L.B. Costa, M.Z. Hernandes, M.M. Rabello, et al., 2-Pyridyl thiazoles as novel anti- Trypanosoma cruzi agents: structural design, synthesis and pharmacological evaluation, Eur. J. Med. Chem. 86 (2014) 48-59, http://dx.doi.org/10.1016/ j.ejmech.2014.08.012.

[32] D.R. Richardson, D.S. Kalinowski, V. Richardson, P.C. Sharpe, D.B. Lovejoy, M. Islam, et al., 2-Acetylpyridine thiosemicarbazones are potent iron chelators and antiproliferative agents: redox activity, iron complexation and characterization of their antitumor activity, J. Med. Chem. 52 (2009) 1459-1470 http://dx.doi.org/10.1021/jm801585u.

[33] G.F. Santoro, M. das Graças Cardoso, L.G.L. Guimarães, A.P.S.P. Salgado, R.F.S. Menna-Barreto, M.J. Soares, Effect of oregano (Origanum vulgare L.) and thyme (Thymus vulgaris L.) essential oils on Trypanosoma cruzi (Protozoa: Kinetoplastida) growth and ultrastructure, Parasitol. Res. 100 (2007) 783-790, http://dx.doi.org/10.1007/s00436-006-0326-5.

[34] C.O. Rodrigues, R. Catisti, S.A. Uyemura, A.E. Vercesi, R. Lira, C. Rodriguez, et al. The sterol composition of Trypanosoma cruzi changes after growth in different culture media and results in different sensitivity to digitonin-permeabilization, J. Eukaryot. Microbiol. 48 (2001) 588-594.

[35] P. Zhan, X. Liu, Z. Li, Z. Fang, Z. Li, D. Wang, et al., Novel 1,2,3-thiadiazole derivatives as HIV-1 NNRTIs with improved potency: synthesis and preliminary SAR studies, Bioorg. Med. Chem. 17 (2009) 5920-5927, http:// dx.doi.org/10.1016/j.bmc.2009.07.004.

[36] R.S. Ferreira, C. Bryant, K.K.H. Ang, J.H. McKerrow, B.K. Shoichet, A.R. Renslo, Divergent modes of enzyme inhibition in a homologous structure-activity series, J. Med. Chem. 52 (2009) 5005-5008, http://dx.doi.org/10.1021/ jm9009229.

[37] E.M. De Souza, A. Lansiaux, C. Bailly, W.D. Wilson, Q. Hu, D.W. Boykin, et al. Phenyl substitution of furamidine markedly potentiates its anti-parasitic activity against Trypanosoma cruzi and Leishmania amazonensis, Biochem. Pharmacol. 68 (2004) 593-600, http://dx.doi.org/10.1016/j.bcp.2004.04.019.

[38] L.R. Garzoni, A. Caldera, M. de N.L. Meirelles, S.L. d Castro, R. Docampo, G.A. Meints, et al., Selective in vitro effects of the farnesyl pyrophosphate synthase inhibitor risedronate on Trypanosoma cruzi, Int. J. Antimicrob. Agents $23 \quad$ (2004) 273-285, http://dx.doi.org/10.1016 j.ijantimicag 2003.07.020.

[39] M.V. Braga, J.A. Urbina, W. de Souza, Effects of squalene synthase inhibitors on the growth and ultrastructure of Trypanosoma cruzi, Int. J. Antimicrob. Agents 24 (2004) 72-78, http://dx.doi.org/10.1016/j.ijantimicag.2003.12.009.

[40] A.P. Dantas, K. Salomão, H.S. Barbosa, S.L. De Castro, The effect of Bulgarian propolis against Trypanosoma cruzi and during its interaction with host cells, Mem. Inst. Oswaldo Cruz. 101 (2006) 207-211, http://dx.doi.org/10.1590/ S0074-02762006000200013.

[41] G.B. Rocha, R.O. Freire, A.M. Simas, J.J.P. Stewart, RM1: a reparameterization of AM1 for H, C, N, O, P, S, F, Cl, Br, and I, J. Comput. Chem. 27 (2006) 1101-1111 http://dx.doi.org/10.1002/jcc.20425.

[42] Spartan "08 Tutorial and User"s Guide: Wavefunction, 2008

[43] G.M. Morris, R. Huey, W. Lindstrom, M.F. Sanner, R.K. Belew, D.S. Goodsell, et al., AutoDock4 and AutoDockTools4: automated docking with selective receptor flexibility, J. Comput. Chem. 30 (2009) 2785-2791, http://dx.doi.org/ $10.1002 /$ jcc. 21256.

[44] J.D. Durrant, J.A. McCammon, BINANA: a novel algorithm for ligand-binding characterization, J. Mol. Graph. Model 29 (2011) 888-893, http://dx.doi.org 10.1016/j.jmgm.2011.01.004.

[45] The PyMOL Molecular Graphics System, Version 1.3 Schrödinger, LLC., (n.d.). 